\title{
Assessing pulmonary hypertension in COPD. Is there a role for computed tomography?
}

This article was published in the following Dove Press journal:

International Journal of Chronic Obstructive Pulmonary Disease

\author{
Florence Coste ${ }^{1,2, *}$ \\ Ilyes Benlala ${ }^{1-3, *}$ \\ Gaël Dournes ${ }^{1-3}$ \\ Pierre-Olivier Girodet ${ }^{1-3}$ \\ François Laurent ${ }^{1-3, *}$ \\ Patrick Berger ${ }^{1-3, *}$ \\ 'University Bordeaux, Centre de \\ Recherche Cardio-Thoracique de \\ Bordeaux, U1045, Bordeaux, F-33000 \\ France; ${ }^{2}$ Inserm, Centre de Recherche \\ Cardio-Thoracique de Bordeaux, U1045, \\ $\mathrm{ClCl} 40 \mathrm{I}$, Bordeaux, F-33000 France; \\ ${ }^{3} \mathrm{CHU}$ de Bordeaux, Service d'Imagerie \\ Thoracique et Cardiovasculaire, Service \\ des Maladies Respiratoires, $\mathrm{ClCl} 40 \mathrm{I}$, \\ Service d'Explorations Fonctionnelles \\ Respiratoires, Pessac, F-33600 France \\ *These authors contributed equally to \\ this work
}

Correspondence: Florence Coste Centre de Recherche Cardio-thoracique de Bordeaux, INSERM UI045, Université Bordeaux, 146 rue Léo Saignat, Bordeaux Cedex 33076, France

Tel +33557574602

Fax +33 $55757 \quad 1695$

Email florence-coste@hotmail.fr

\begin{abstract}
Pulmonary hypertension (PH) is a common complication of chronic obstructive pulmonary disease (COPD) and is associated with increased morbidity and mortality. Reference standard method to diagnose $\mathrm{PH}$ is right heart catheterization. Several noninvasive imaging techniques have been employed in the detection of PH. Among them, computed tomography (CT) is the most commonly used for phenotyping and detecting complications of COPD. Several CT findings have also been described in patients with severe PH. Nevertheless, CT analysis is currently based on visual findings which can lead to reproducibility failure. Therefore, there is a need for quantification in order to assess objective criteria. In this review, progresses in automated analyses of CT parameters and their values in predicting PH and COPD outcomes are presented.
\end{abstract}

Keywords: computed tomography, pulmonary hypertension, COPD, prediction

\section{Introduction}

Chronic obstructive pulmonary disease (COPD) is a common, preventable and treatable disease that is characterized by persistent respiratory symptoms (ie, dyspnea, cough and/or sputum production) and airflow limitation that is due to airway and/or alveolar abnormalities usually caused by significant exposure to noxious particles or gases. ${ }^{1}$ COPD has an increasing prevalence worldwide and is mainly caused by tobacco smoke exposure. Diagnosis is based on spirometry with a post-bronchodilator $\mathrm{FEV}_{1} / \mathrm{FVC}$ ratio lower than $0.70 .^{2}$ The level of COPD severity is now assessed using both functional (ie, $\mathrm{FEV}_{1}$ in percentage of predicted values) and clinical data (ie, symptoms scores (CAT and/or mMRC) and the number of exacerbations within the previous 12 months). ${ }^{2}$

COPD is frequently associated with comorbidities. Among them, pulmonary hypertension $(\mathrm{PH})$ is causally related to COPD. $\mathrm{PH}$ is defined by a mean pulmonary arterial pressure (mPAP) equal or higher than $25 \mathrm{mmHg}$ at rest, measured using the reference method right heart catheterization (RHC). ${ }^{3-6}$ The prevalence of $\mathrm{PH}$ and the underlying pathophysiologic processes in patients suffering from COPD remain unclear. Indeed, prevalence increases with COPD severity, and its rate has been reported varying from $20 \%$ to $90 \% .^{7-11}$ An increase of mPAP is associated with an increased number of hospitalizations, morbidity and mortality in COPD. ${ }^{12-15}$ The few patients with severe PH secondary to COPD, defined at RHC as a mPAP $\geq 35$ $\mathrm{mmHg}$ or $\mathrm{mPAP} \geq 25$ with cardiac index $(\mathrm{CI})<21 / \mathrm{min} / \mathrm{m}^{2}$, are considered as a subgroup with potentially serious and high complication rate. ${ }^{5}$ So far, only a few studies have evaluated the effects of vasodilator in patients with severe $\mathrm{PH}$ 
secondary to COPD, meaning that this subpopulation might benefit from a specific care. ${ }^{16-18}$

There are no specific clinical symptoms of $\mathrm{PH}$, and this complication starts insidiously, the most common symptom being dyspnea. ${ }^{8} \mathrm{PH}$ in COPD patients has been shown to be associated with an increased exacerbation rate, ${ }^{8}$ worsen exercise capacity ${ }^{8}$ and a poorer prognosis. ${ }^{8,13,15}$ For instance in a study from Andersen et al, ${ }^{19}$ the survival rate was $63 \%$ for COPD patients without $\mathrm{PH}$ vs $37 \%$ in those with $\mathrm{PH}$. The most reliable index of $\mathrm{PH}$ is the mPAP, a parameter so far measured only by RHC, an invasive technique which remains the reference method for the diagnosis of $\mathrm{PH}^{3,4}$ This unique test enables a direct assessment of various pulmonary arterial pressure indices, systolic, diastolic, mean and capillary pressures, as well as resistance, cardiac output and therefore enables to differentiate pre- and post-capillary $\mathrm{PH},{ }^{20,21}$ a major way for assessing PH etiology. However, RHC can be responsible for the occurrence of adverse events, related to complication to venous access (such as hematoma, pneumothorax), but also those due to arrhythmias, hypotensive episodes due to vagal reaction or pulmonary vasoreactivity testing. Whereas RHC serious adverse events remain rare in experienced centers (ie, $1.1 \%$ and mortality is extremely rare), ${ }^{22}$ RHC is not totally safe, especially in unstable patients. Thus, noninvasive diagnosis techniques able to reduce the delay in diagnosing $\mathrm{PH}$ and to avoid side effects of RHC are suitable. Echocardiography has been proposed to evaluate systolic pulmonary arterial pressure (sPAP), which is correlated with mPAP, but its specificity is low. ${ }^{23}$ However, echocardiography remains the primary tool for patients screening, especially in others PH's etiologies. ${ }^{4}$ Nevertheless, echocardiography may be technically difficult to perform, especially in patients with an inflated thorax and/or emphysema. Computed tomography (CT) is a common tool to investigate COPD and its role is crucial in the diagnosis and characterization of emphysema, airway disease, and advocated in various clinical situations such as follow-up, exacerbations, pre-operative surgery and lung transplantation. ${ }^{2,24-27} \mathrm{CT}$ is a useful tool to assess in vivo observation; nevertheless, radiation exposure risk is not null, ${ }^{28}$ in addition, large inappropriate indications of this examination might lead to overrun radiology departments. Moreover, iodine contrast injection and repetitive CT acquisitions are needed to assess hemodynamic alterations related to $\mathrm{PH}$ which could increase risk of radiation and adverse reactions to contrast injection. Other interesting technics could be used to study $\mathrm{PH}$, such as Dual energy $\mathrm{CT},{ }^{29}$ or magnetic resonance imaging (MRI). MRI is much less employed in lung diseases due to the low signal intensity of the lung but recent improvements have been published ${ }^{30-34}$ and MRI is currently the best tool for evaluating heart morphology and function, ${ }^{35}$ or estimating pulmonary arterial pressure using phase contrast MRI. ${ }^{36}$

$\mathrm{CT}$ is currently performed for screening $\mathrm{PH}$ etiology, notably in the assessment of chronic thromboembolic $\mathrm{PH}$, lung disease, pulmonary arterial hypertension and pulmonary veno-occlusive disease. ${ }^{37-40} \mathrm{CT}$ is also used as a prognostic marker in patients with $\mathrm{PH}^{4}{ }^{41}$

This review is focused on the role of $\mathrm{CT}$ in detecting $\mathrm{PH}$ in COPD patients. We will first describe the technical characteristics of CT and then we will discuss the morphological assessment of the parenchymal, bronchial and vascular compartments in COPD and their relationships with $\mathrm{PH}$ with a special interest in quantitative characterization.

\section{COPD a multi-compartment disease}

COPD is defined by functional irreversible airflow limitation but characteristic morphological changes are present in lung parenchyma, airways and pulmonary vasculature. ${ }^{1,42}$ Airflow limitation can be, at least partially, explained by parenchymal destruction due to emphysema. ${ }^{1}$ Emphysema is defined histologically by alveolar wall destruction and can be assessed visually using $\mathrm{CT}^{43-45}$ The severity of emphysema can also be measured by quantitative CT indices reflecting the low attenuation area due to lung destruction. These quantitative indices have been shown to correlate with macroscopic and microscopic changes histologically. ${ }^{46,47}$

Proximal bronchial wall thickening is a common feature in COPD. ${ }^{48,49}$ Histological characteristics of proximal airways include increased infiltration of $\mathrm{CD} 8(+) \mathrm{T}$ lymphocytes, CD3+ T lymphocytes, macrophages. ${ }^{48-50}$ This thickening appeared to be more important in a particular COPD-phenotype characterized by less severe respiratory disease, older subjects and higher rates of obesity and cardiovascular comorbidities. ${ }^{51}$ Such a proximal thickening can be directly assessed by $\mathrm{CT}$ using $2 \mathrm{D}^{52,53}$ and $3 \mathrm{D}$ reconstruction. ${ }^{54-60}$

Bronchial wall thickening is however predominant in distal airways. ${ }^{61-65}$ At histological level, it associates luminal exudates, inflammatory cell infiltration and airway remodeling including peribronchial fibrosis, epithelial 
metaplasia, mucous gland hypertrophy and increased bronchial smooth muscle mass of the small airways. ${ }^{62,66}$ The higher the severity of COPD based on decreased $\mathrm{FEV}_{1}$, the higher the histological abnormalities. ${ }^{66}$ Moreover, inflammatory cell infiltration is related with tobacco smoking. ${ }^{67}$ A loss of small airways has been observed using microCT, a high-resolution imaging technique dedicated to small samples or animal models, contributing to airflow limitation. ${ }^{62}$ In humans, the small airway disease can be assessed two-folds morphologically: directly by showing centrilobular opacities and indirectly by using air trapping. ${ }^{67-69}$ Such an air trapping has been shown to correlate with the number of inflammatory cells (ie, neutrophils and mast cells) infiltrating the bronchial smooth muscle layer. $^{67}$

It has been shown that the toxicity of tobacco smoke affects bronchi and parenchyma, but can also directly alter pulmonary vessels both in animals ${ }^{70}$ and humans. ${ }^{6,71}$ At histological level, pulmonary arterial remodeling appeared to be more important in COPD than in control subjects, and is particularly important in upper lobe and in small muscular pulmonary arteries. ${ }^{72}$ Those vessel alterations are multiples and can happen at initial stage of $\mathrm{COPD}^{71}$ with endothelial dysfunction, inflammation, suggesting that the history of $\mathrm{PH}$ in COPD might be related with cigarette-smoke-induced endothelial alterations. ${ }^{73,74}$ The quantitative amount of emphysema in COPD was often negatively correlated to pulmonary microvasculature abnormalities measured using $\mathrm{CT}^{75-79}$ except for Wrobel et al, ${ }^{72}$ which did not find any significant correlation.

\section{CT technical considerations}

CT scan is the most reliable imaging modality for imaging pulmonary diseases, and it is available and commonly used in routine practice. The new generation of multidetector CT scanners allows acquisition of the whole lung in one breath hold with a submillimetric slice thickness and isotropic voxels using adequate matrix.

The COPD Gene study provides recommendations to standardize CT acquisition parameters in order to obtain high signal-to-noise ratio and accordingly accurate assessment of the images. ${ }^{80}$ Thin sections with non-contrastenhanced volumetric acquisition is a standard technique for COPD imaging. ${ }^{81}$ However, intravenous iodinated contrast material is necessary in case of exacerbations or suspected pulmonary embolism. Standard reconstruction algorithm (smooth filter) is required for quantitative automatic analysis. ${ }^{82}$ Spirometric gated acquisition have been proposed to improve quantitative assessment, but is only used in dedicated research programs due to its complexity and low availability. ${ }^{83}$ Although COPD patients are older and radiation risks are thus minimized, balance between radiation dose and image quality should be considered. Misevaluation of quantitative parameters because of noisy images leads to standard tube parameters $(\mathrm{kVp}$ and mAs). ${ }^{84}$ However, low-dose CT acquisition with new iterative reconstruction algorithms allows noise reduction with acceptable quantitative measurements. ${ }^{83,85}$

\section{Lung parenchyma}

Historically, parenchymal alteration, and more precisely, emphysema, has been the first lung component investigated in order to explain PH in COPD. Indeed, emphysema is a major characteristic of COPD that could be quantified in patients when $\mathrm{CT}$ is performed. At CT, emphysema can be quantitatively evaluated, using low attenuation area percent (LAA $\%$ ) derived from the voxel frequency distribution histogram. Several thresholds have been proposed but the most commonly employed is the value of -950 Hounsfield units $(\mathrm{HU})^{45,46,86-89}$ (see Figure 1). It has been initially hypothesized that emphysema was correlated with mPAP. However, surprisingly, no relationship between $\mathrm{PH}$ and emphysema has been demonstrated neither in human nor in animal models. $^{7,44,45,90,91}$ In addition, no significant difference in LAA\% between COPD patients with or without $\mathrm{PH}$ was observed. $^{45,92,93}$ Nonetheless, one single study observed that among COPD patients with $\mathrm{PH}$, the LAA\% measured using automated CT was correlated with right ventricular (RV) dysfunction. ${ }^{94}$ Emphysema can also be reflected using CT scan with the threshold of $-960 \mathrm{HU}$, the evaluation of the first percentile, ${ }^{95}$ or in longitudinal studies, the $15^{\text {th }}$ percentile is preferred to follow-up emphysema changes. ${ }^{96}$

\section{Proximal bronchi}

Bronchi can be studied using CT with $2 \mathrm{D}^{52,53}$ or $3 \mathrm{D}^{54-60}$ acquisitions. Various methods of bronchial segmentation and various parameters have been proposed, with so far no consensus (see Figure 2). Lumen area, wall area, wall area \%, wall thickness and -Pi10, that reflects the normalized wall area of a theoretical $10-\mathrm{mm}$ bronchi section area, have been proposed as indices for quantitating the severity of bronchial wall changes. ${ }^{45,52,86,89,97-101}$ We have demonstrated that bronchial thickness assessed by CT was increased in COPD patients with $\mathrm{PH}$ as compared to that of COPD patients without $\mathrm{PH}$, whereas demographic, clinical and functional data (except $\mathrm{PaO}_{2}$ and 6 mins walk test 


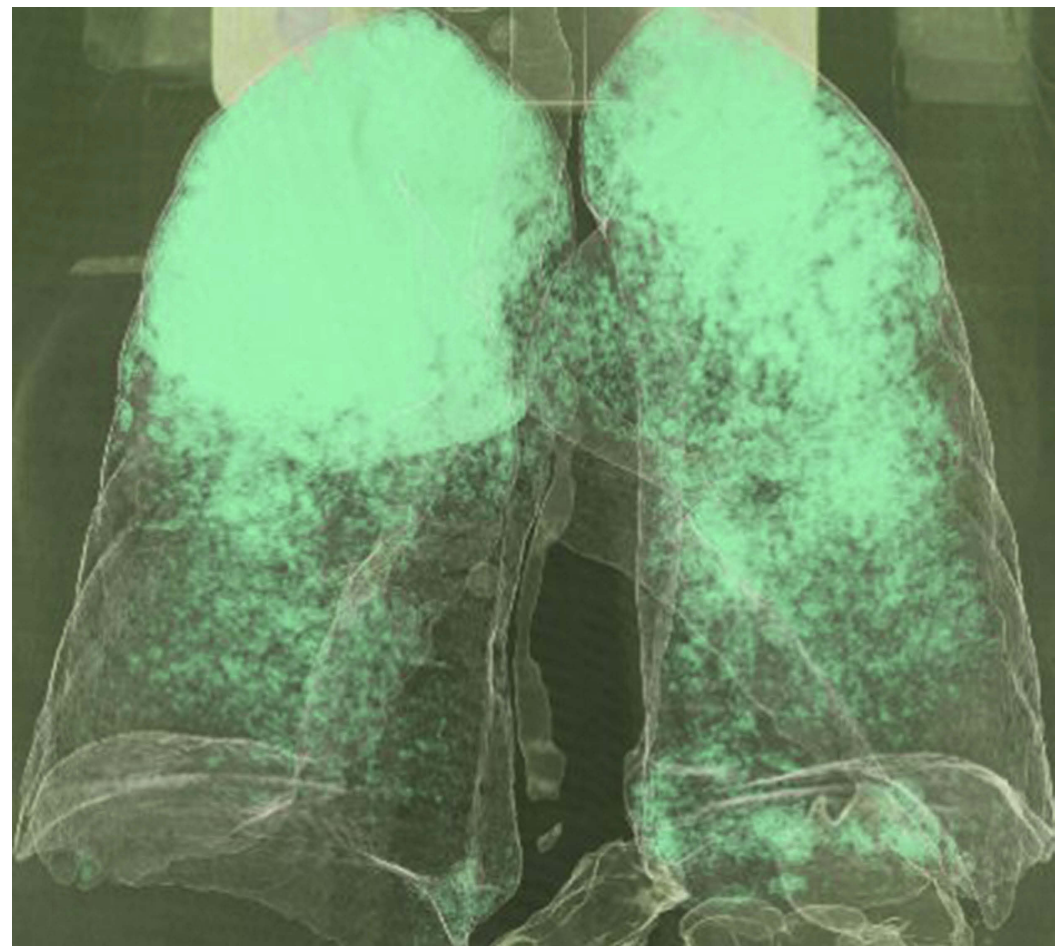

Figure I Reconstructed chest CT scan in COPD patient. This image was acquired with high-spatial-frequency algorithm reconstruction using fully automated Pulmo3D software (Siemens, Munich, Germany). Low attenuation area (LAA\%) was derived from the voxel frequency distribution histogram and represented the percentage of lung voxels less than $-950 \mathrm{HU}$. In this COPD patient, LAA value was $23 \%$

Abbreviations: COPD, chronic obstructive pulmonary disease; $\mathrm{CT}$, computed tomography.

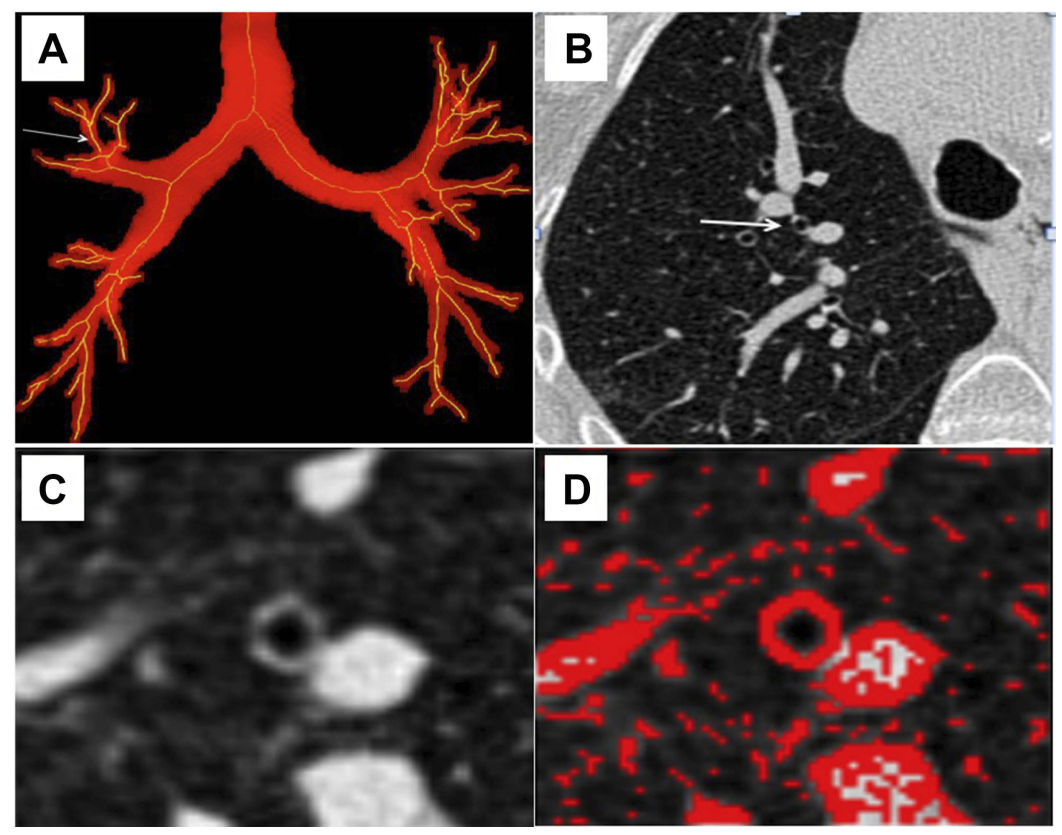

Figure 2 Bronchi segmentation. (A) Frontal view of a propagation algorithm to obtain a skeleton binary volume based on bi-thresholding. Arrow shows bronchi in which measurements were assessed. (B) Peripheral bronchus is designated (arrow) on a native transverse thin-section CT. (C) Thin-section CT scan used to obtain measurements. (D) A Laplacian of Gaussian algorithm was assessed to segment the designed airway and measure bronchial thickness.

Abbreviation: CT, computed tomography. 
distance, not surprisingly) remain unchanged. ${ }^{45}$ Moreover, a correlation between bronchial wall thickness and mPAP has been reported both in $\mathrm{PH}^{45}$ and in severe $\mathrm{PH}$ secondary to COPD. ${ }^{86,102}$ In addition, bronchial wall thickness measured using CT was correlated to histological measurements of airway remodeling, ${ }^{52}$ to exacerbation frequency, ${ }^{103}$ respiratory symptoms ${ }^{89}$ and to $\mathrm{FEV} 1 \%{ }^{104}$

\section{Small airways}

Since obstruction of small airways, defined as airways with a diameter under $2 \mathrm{~mm}$, has been shown to be the main determinant of obstruction in COPD, ${ }^{62-65}$ some imaging technics have intended to characterize small airway disease in COPD. Mosaic attenuation at inspiratory and air trapping at expiratory $\mathrm{CT}$ reflect small airway disease. Both are related to a decreased lung attenuation and therefore cannot be easily distinguished from emphysema. ${ }^{105}$ However, we have found that air trapping was correlated with inflammatory cell infiltration and might reflect peripheral airway obstruction in patients exposed to cigarette smoking. ${ }^{67}$ Galbán et al have assessed both expiratory and inspiratory CT using parametric response map in order to estimate functional small airway disease in COPD patients. ${ }^{106}$ Parametric response map was able to differentiate COPD phenotypes. In addition, Matsuoka et al calculated relative volume change (expiratory minus inspiratory relative volume) using CT with the threshold of $-860 \mathrm{HU}$ that was correlated with airway dysfunction (ie, assessed at PFTs) in COPD regardless of the degree of emphysema. ${ }^{68}$ To the best of our knowledge, there is no study dedicated to the small airways of COPD patients with PH using CT.

\section{Central vessels}

In COPD, a correlation has been shown between mPAP and enlargement of the main pulmonary artery truncus (MAP) diameter, and this increase is observed when MAP is normalized by ascending aorta diameter (MAP/AO). ${ }^{86,107-110}$ Usually, normalization is made on ascending aorta ${ }^{107,108,111,112}$ (see Figure 3) but it has also been done on descending aorta. ${ }^{21}$ Usually, MAP widest dimension is measured on axial CT images, on inspiratory acquisition, at bifurcation level, and, AO is measured on the same image. ${ }^{107,108,111,112}$ Descending aorta is also measured at the same level. ${ }^{112}$ Thresholds values to detect $\mathrm{PH}$ in COPD patients are: MAP $\geq 29 \mathrm{~mm}^{21,113,114}$ and MAP/AO $>1 .{ }^{107,110,111,115,116}$

Increased MAP/AO ratio, a very simple index measured on a routine $\mathrm{CT}$ acquisition, has been shown linked to an increased risk of exacerbation in $\mathrm{COPD}^{108,111,117}$ and a lower 6-mins walk distance. ${ }^{118}$ Mortality in COPD population was also correlated to $\mathrm{MAP} / \mathrm{AO}$ ratio in some reports $^{115,119}$ but not in others. ${ }^{108,110}$ Interestingly, this ratio was not correlated to mortality in the general population. $^{119}$ However, in healthy children, the ratio $\mathrm{MAP} / \mathrm{AO}$ is higher than one, so the threshold of 1 cannot be applied in children. ${ }^{112}$

Pulmonary artery distensibility, that reflects elasticity using volume variations of the MAP between diastole and systole, is decreased in $\mathrm{PH} .{ }^{3,4,120}$ The increase of stiffness is

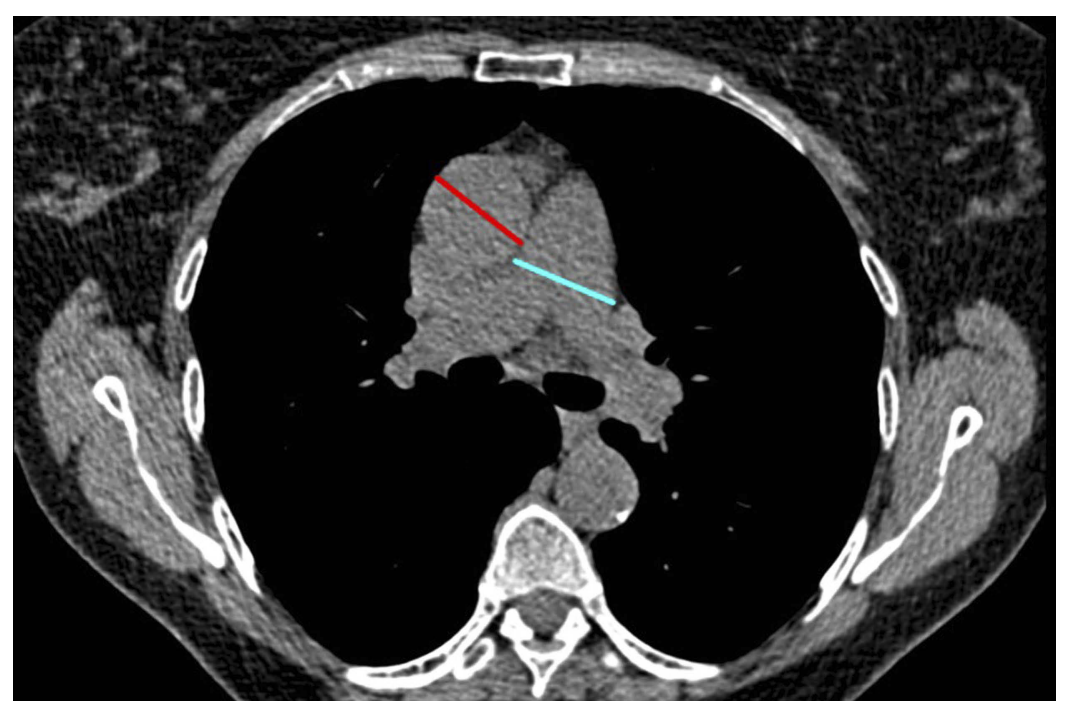

Figure 3 Pulmonary artery and aorta measurements. Ratio measurement obtained in a COPD patient in a transverse CT section. Abbreviations: COPD, chronic obstructive pulmonary disease; $\mathrm{CT}$, computed tomography. 
also observed in group 3 of $\mathrm{PH}^{121}$ and in $\mathrm{PH}$ related to COPD. ${ }^{122}$ Cardiac magnetic resonance (CMR) or ECGgated CT can be also used to evaluate PA stiffness. ${ }^{3,4,120,121}$

In addition, dynamic-contrast-enhanced CT can be used to discriminate patients with or without $\mathrm{PH}$ from different etiology. ${ }^{123}$ A delayed flow of contrast and a reduced bolus propagation speed were observed in $\mathrm{PH}$ in comparison to control patients. Regions of interests were placed in the MAP and in the left and right pulmonary arteries. However, this study presented some limitations since bolus propagation also reflects the left heart function, the respiratory function and the speed of injection. ${ }^{123}$

\section{Small vessels}

The segmental pulmonary artery-to-bronchus ratio, semiquantitatively evaluated for apical and posterior segments that run perpendicularly to the axial CT-scan, is positively correlated with mPAP. ${ }^{124}$ Ratio $>1$ in three or more lobes is specific of the presence of $\mathrm{PH}^{113,124}$ in group 3 of $\mathrm{PH}$ classification that also comprise COPD. ${ }^{125}$ In the same way, the size of the segmental arterial diameters is also positively correlated with $\mathrm{mPAP}^{124}$ in group 3 of $\mathrm{PH}^{125}$

Regarding small pulmonary arteries, several of their characteristics have been studied, notably, number, volumes and areas. CT is an efficient tool in order to evaluate in vivo alterations of vessels, follow-up of illness or evaluating drug effects.

Some tools have been developed using $2 \mathrm{D}^{35,79,86,102}$ (see Figure 4) or $3 \mathrm{D}^{78,118,126}$ reconstructions.

Using 2D reconstruction on CT images, an automated measurement has been assessed using a free software Image J. These automated measurements allowed the visualization of small vessels alterations first on $3 \mathrm{CT}$ slices ${ }^{44,127,128}$ and then on the whole lung. ${ }^{86,102}$ Software enables calculation of the percentage of cross-sectional areas $(\mathrm{CSA} \%)$ of small pulmonary vessels under $5 \mathrm{~mm}^{2}$ $\left(\% \mathrm{CSA}_{<5}\right)$ and between 5 and $10 \mathrm{~mm}^{2}\left(\mathrm{CSA}_{5-10}\right)$, normalized by lung area, measuring subsubsegmental and subsegmental levels, respectively. Thus, in COPD patients without severe $\mathrm{PH}$, the correlation between $\% \mathrm{CSA}_{<5}$ and mPAP was negative ${ }^{44,86}$ whereas in COPD with severe PH correlation was positive. $^{86,102}$

The $3 \mathrm{D}$ reconstruction technique allowed to measure volumes of small vessels. ${ }^{78,118,129}$ In both studies, ${ }^{78,118}$ index using 3D for assessment of pulmonary vessels was negatively correlated with MAP. For Ma et al, ${ }^{78} 3 \mathrm{D}$ and $2 \mathrm{D}$ techniques were correlated. Studies using $2 \mathrm{D}$ and $3 \mathrm{D}$ are in the same line and showed a negative correlation between small pulmonary vessels and mPAP in COPD patients with most of the time moderate $\mathrm{PH}$. As mentioned by others, all those vascular impairments support a vascular etiology of smoking-induced lung disease. ${ }^{6,130} \mathrm{CT}$ metrics, such as $\% \mathrm{CSA}_{<5}$, also allowed evaluation of the effect of pulmonary vasodilators in patients with $\mathrm{PH}$ related to COPD. ${ }^{79}$

In the automated measurements previously reported, pulmonary arteries were never separated from veins and this may affect the sensitivity of the technique. Tools have been developed in 3D in order to circumvent this limitation but not employed, to the best of our knowledge, for evaluating PH in COPD patients. ${ }^{126,129,131,132}$ A summary of vessels analyses is presented in Table 1 .

\section{Scores}

As mentioned above, several parameters reflecting various components in COPD are modified in COPD patients with PH. Building a score involving these parameters can be a strategy to improve the detection and the severity assessment of $\mathrm{PH}$ in COPD.

Tan et al have associated MAP $\geq 29 \mathrm{~mm}$ with artery-tobronchus ratio $>1$ in 3 or 4 lobes and have reached a specificity of $100 \%$ for detecting $\mathrm{PH}$ in patients suffering from parenchymal lung diseases. ${ }^{113}$

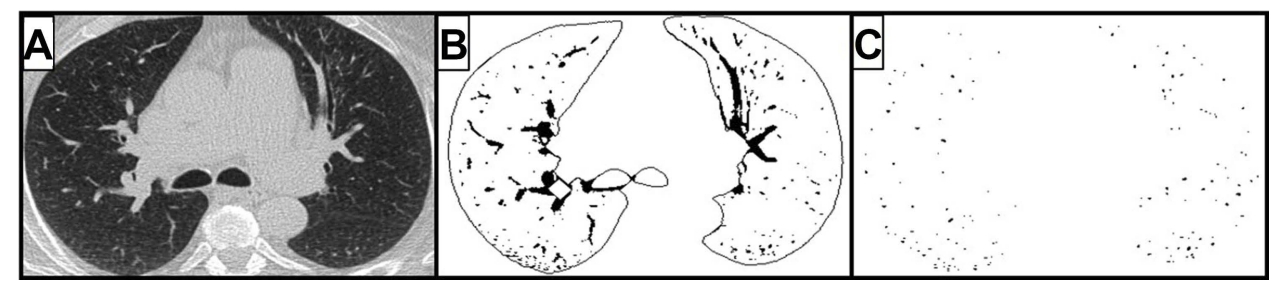

Figure 4 Measurement of cross-sectional areas (CSA) of small pulmonary vessels using Image J free-software. (A) CT image segmented within the threshold values from -500 to $-1024 \mathrm{HU}$ of lung field. (B) Segmented image segmented into binary images. (C) Mask image for the particle analysis after setting circularity within [0.9-I.0] and vessel size within [0-5] $\mathrm{mm}^{2}$.

Abbreviation: $\mathrm{CT}$, computed tomography. 


\begin{tabular}{|c|c|c|c|c|c|c|c|c|c|c|c|}
\hline 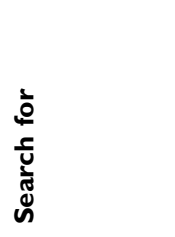 & 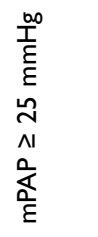 & 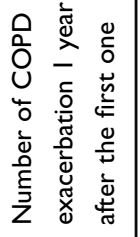 & 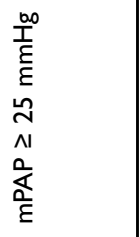 & 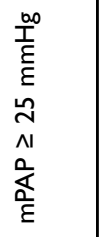 & 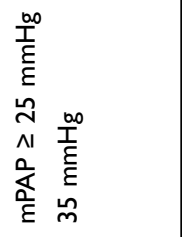 & 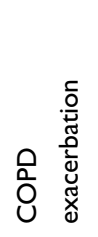 & 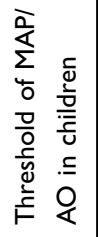 & 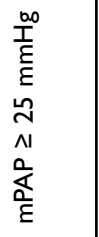 & 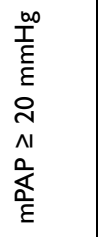 & 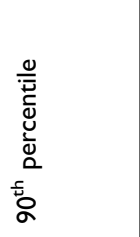 & 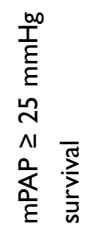 \\
\hline 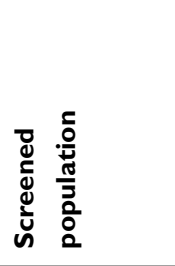 & 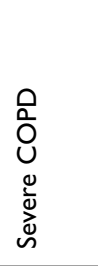 & 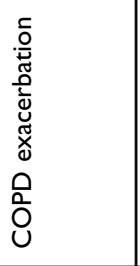 & 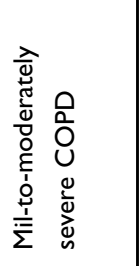 & $\begin{array}{l}\text { Ò } \\
\text { Oे }\end{array}$ & $\begin{array}{l}0 \\
\text { ò }\end{array}$ & 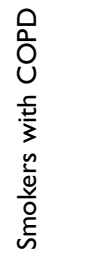 & 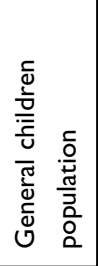 & 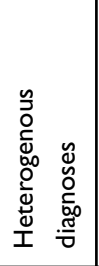 & 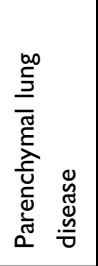 & 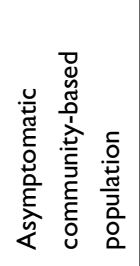 & 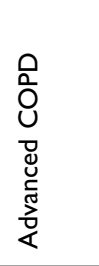 \\
\hline 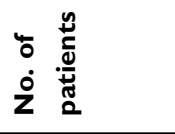 & 이 & 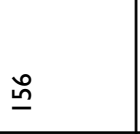 & $\stackrel{\infty}{\infty}$ & 음 & 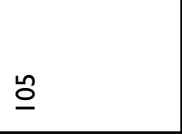 & $\begin{array}{l}\stackrel{+}{0} \\
\text { ț }\end{array}$ & ஓ্ণ & 흐 & $\stackrel{\infty}{\sim}$ & $\frac{\bar{N}}{m}$ & นก \\
\hline 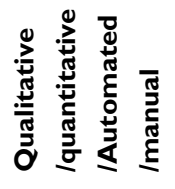 & 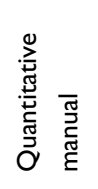 & 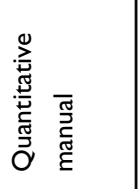 & 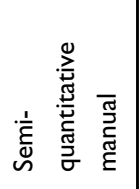 & 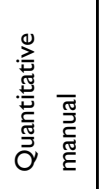 & 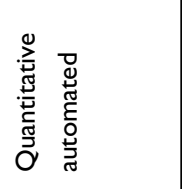 & 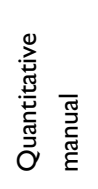 & 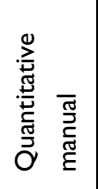 & 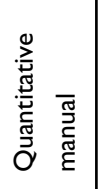 & 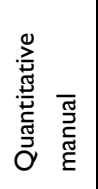 & 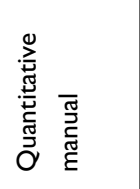 & 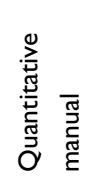 \\
\hline 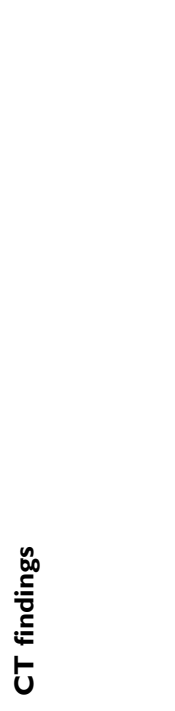 & 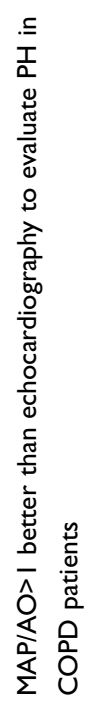 & 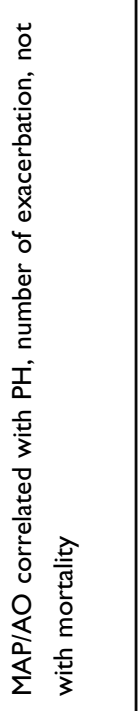 & 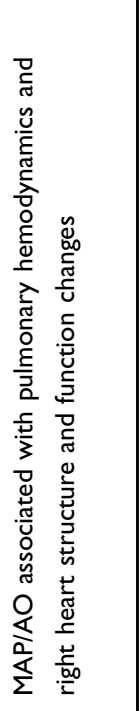 & 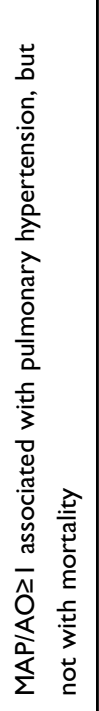 & 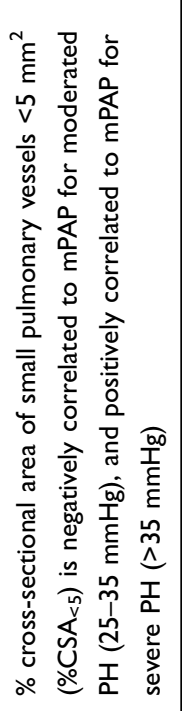 & 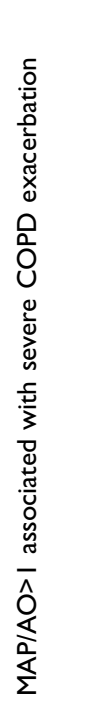 & 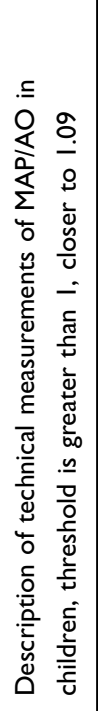 & 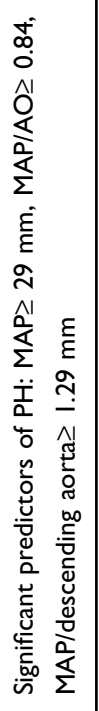 & 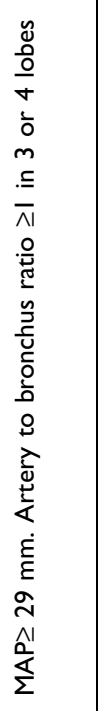 & 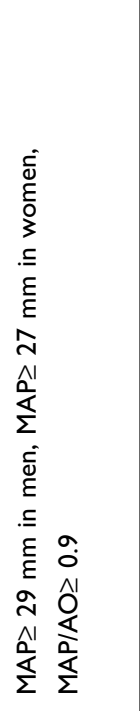 & 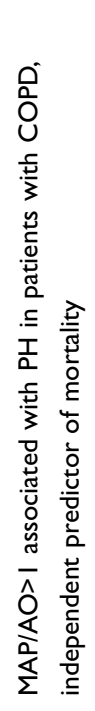 \\
\hline 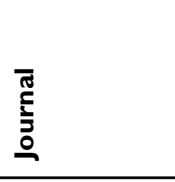 & 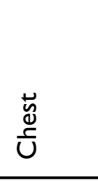 & 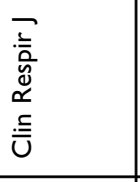 & 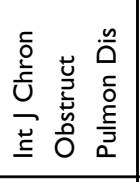 & 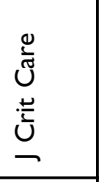 & 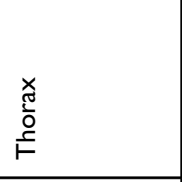 & $\frac{\Sigma}{\text { 耍 }}$ & $\frac{\alpha}{<}$ & 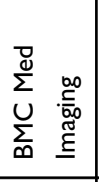 & 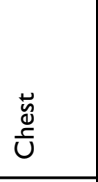 & 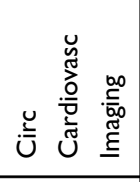 & 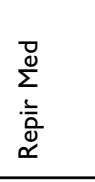 \\
\hline 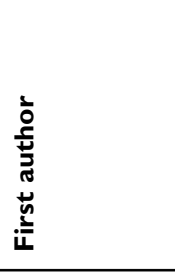 & 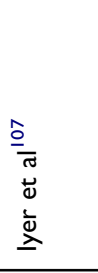 & 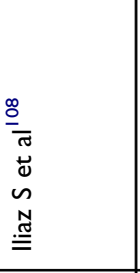 & 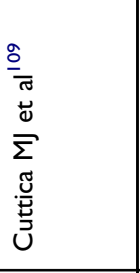 & 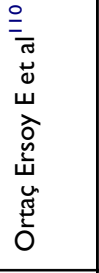 & 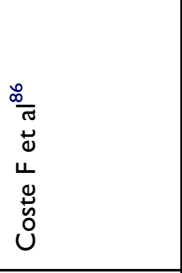 & 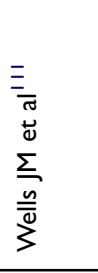 & 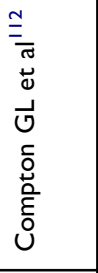 & 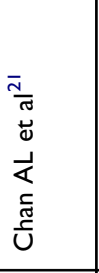 & 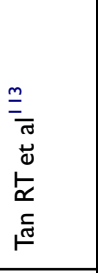 & 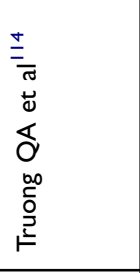 & 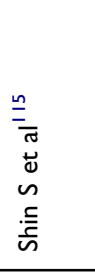 \\
\hline 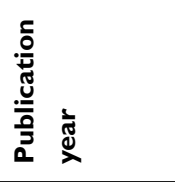 & $\frac{\pi}{2}$ & $\overline{\bar{i}}$ & 호 & $\frac{0}{2}$ & $\stackrel{\circ}{\stackrel{2}{2}}$ & $\frac{1}{2}$ & $\stackrel{\frac{n}{2}}{i}$ & $\overline{\bar{i}}$ & $\stackrel{\infty}{\sigma}$ & $\frac{\sim}{i}$ & $\stackrel{\nabla}{\circ}$ \\
\hline
\end{tabular}




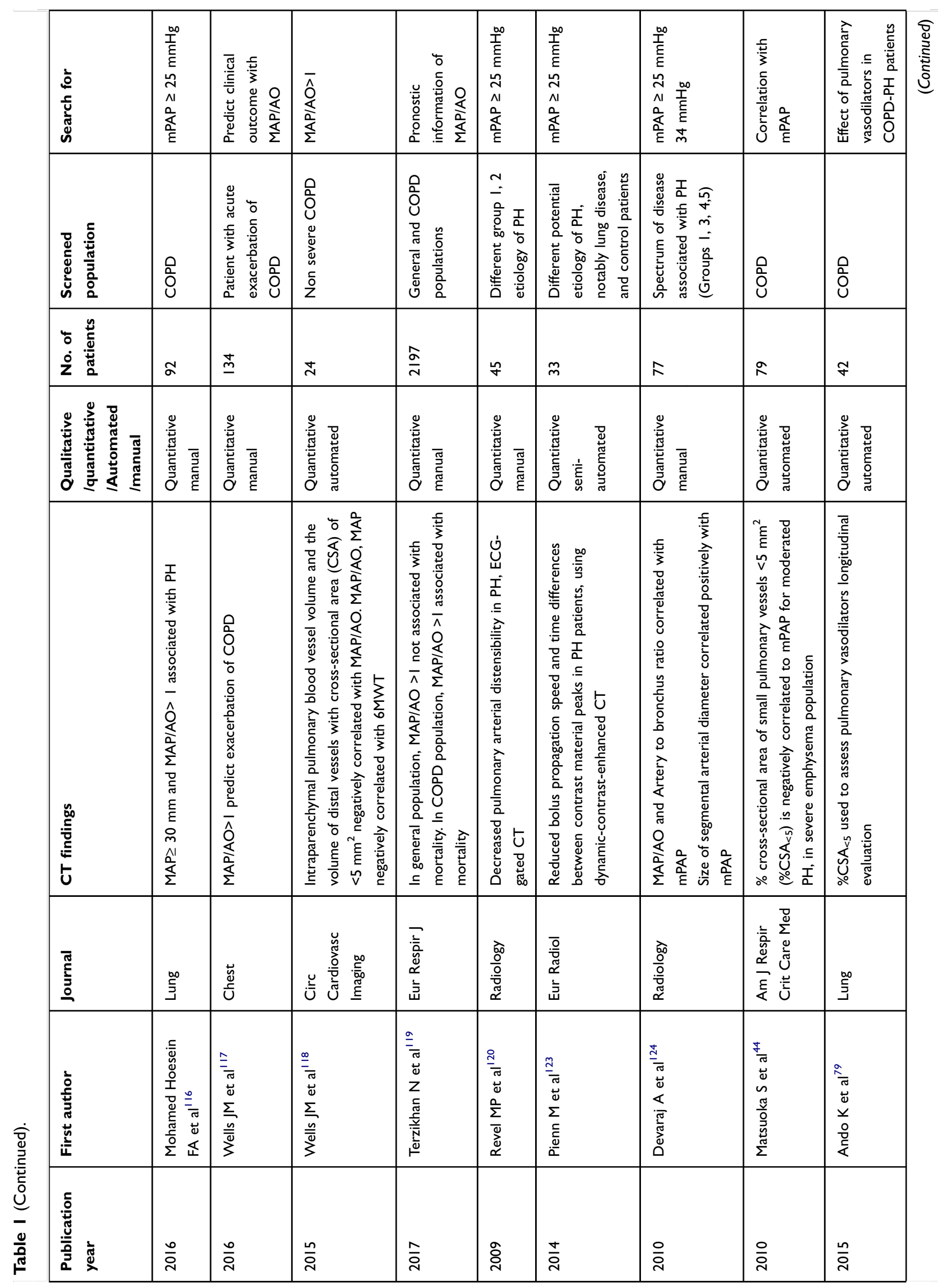




\begin{tabular}{|c|c|c|c|c|c|c|c|c|}
\hline 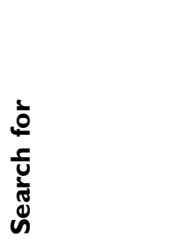 & 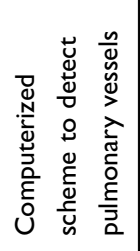 & 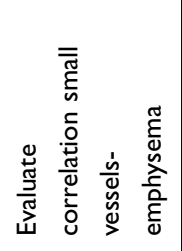 & 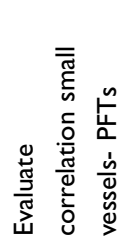 & 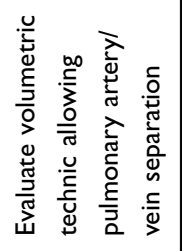 & 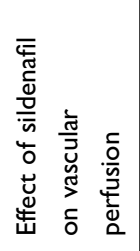 & 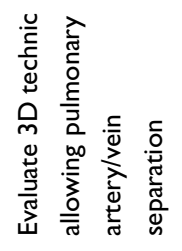 & 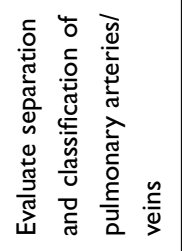 & 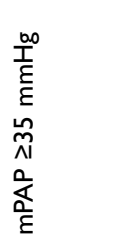 \\
\hline 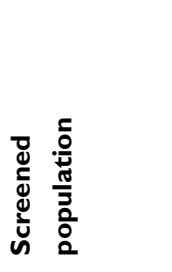 & 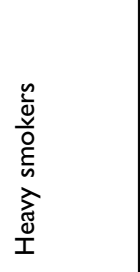 & 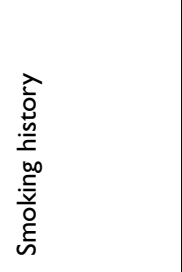 & 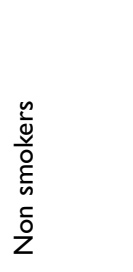 & $\begin{array}{l}0 \\
0 \\
0\end{array}$ & 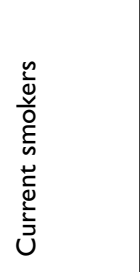 & 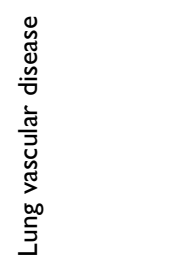 & 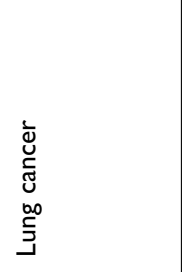 & $\begin{array}{l}0 \\
0 \\
0\end{array}$ \\
\hline 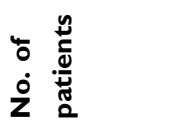 & $\underline{\delta}$ & $\underline{\Xi}$ & ஓ & 으 & $\simeq$ & $\stackrel{\sim}{\sim}$ & นn & $\stackrel{ \pm}{\sim}$ \\
\hline 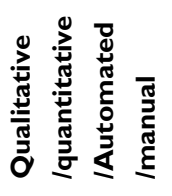 & 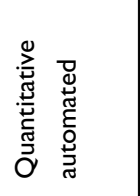 & 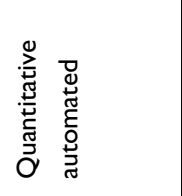 & 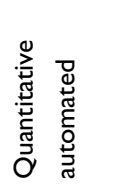 & 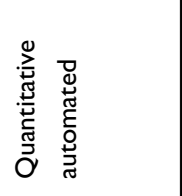 & 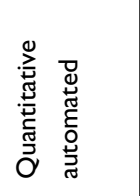 & 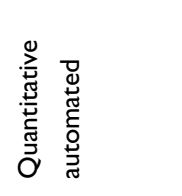 & 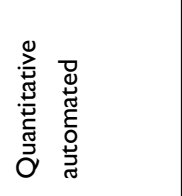 & 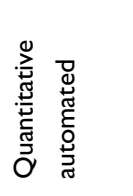 \\
\hline 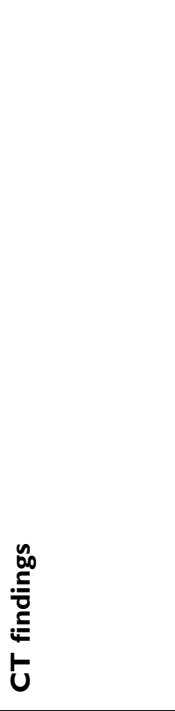 & 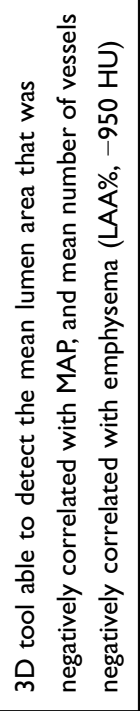 & 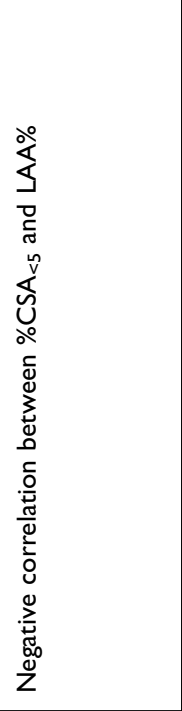 & 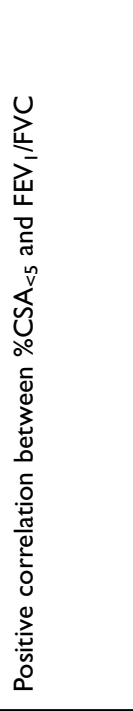 & 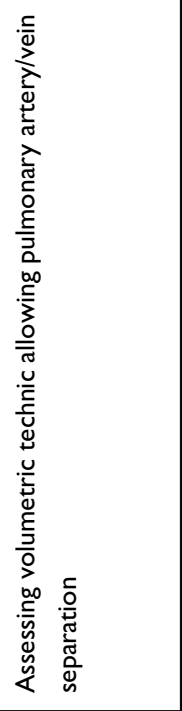 & 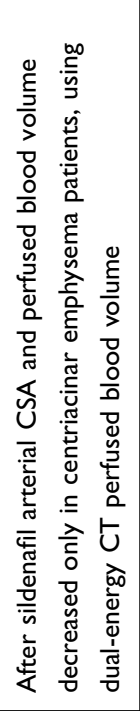 & 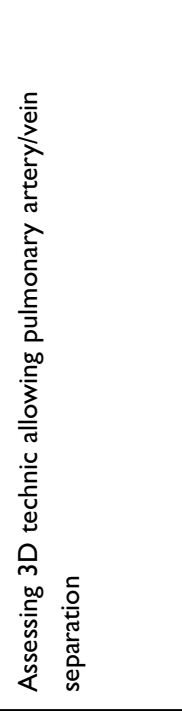 & 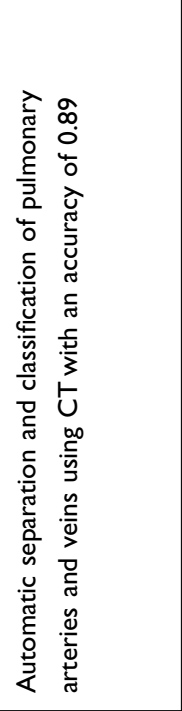 & 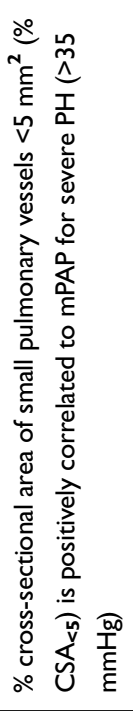 \\
\hline 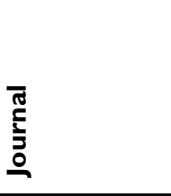 & 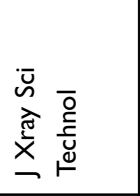 & 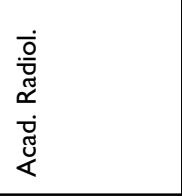 & 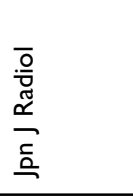 & $\begin{array}{l}\stackrel{n}{a} \\
\frac{a}{n} \\
\overline{0} \\
\sum\end{array}$ & 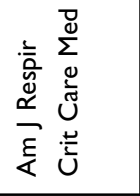 & 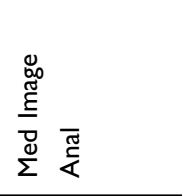 & 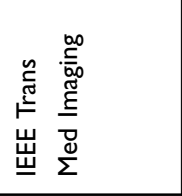 & 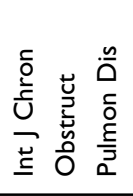 \\
\hline 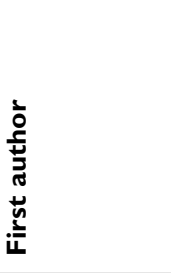 & 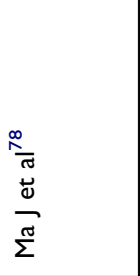 & 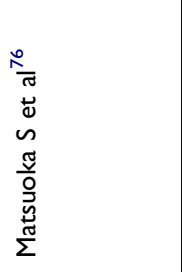 & 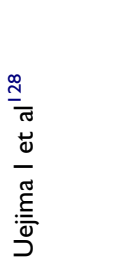 & 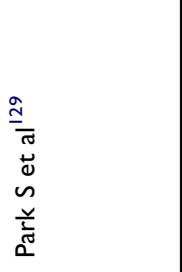 & 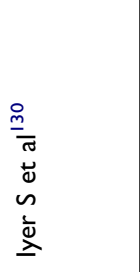 & 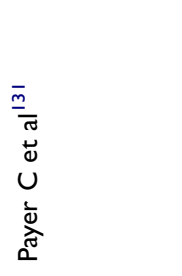 & 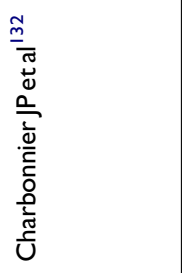 & 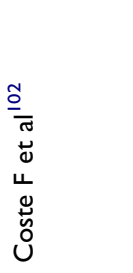 \\
\hline 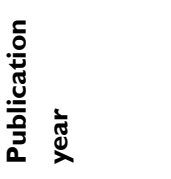 & $\overline{\bar{d}}$ & $\overline{\bar{i}}$ & $\overline{\bar{i}}$ & $\frac{m}{\grave{n}}$ & $\stackrel{\circ}{\circ}$ & $\stackrel{\circ}{\circ}$ & $\stackrel{\circ}{\circ}$ & $\stackrel{\circ}{\bar{c}}$ \\
\hline
\end{tabular}




\begin{tabular}{|c|c|c|c|c|c|c|c|c|}
\hline 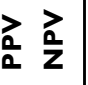 & $\S$ & $\S$ & & ஸ్రి & $\overleftarrow{z} \mathbb{z}$ & ๙ั & 。̊ & कo \\
\hline 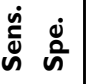 & $\S \stackrel{8}{8}$ & ภ̊ำ & $\begin{array}{c}\stackrel{c}{0} \\
0 \\
0\end{array}$ & $\begin{array}{ll}\substack{n \\
0 \\
0} & \infty \\
0\end{array}$ & 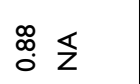 & 옹 & $\begin{array}{c}\alpha \\
\text { ô. } \\
0\end{array}$ & $\frac{\mathrm{m}}{\mathrm{C}}$ \\
\hline 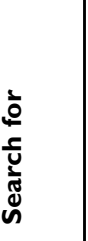 & 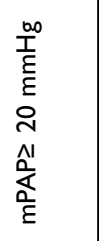 & 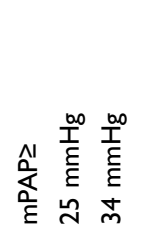 & & 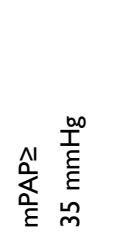 & 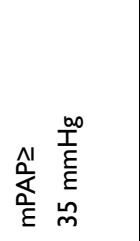 & 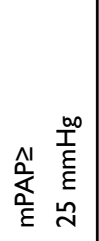 & & \\
\hline 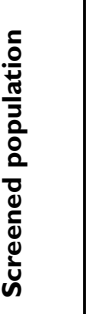 & 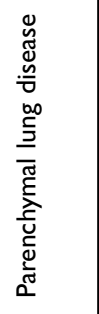 & 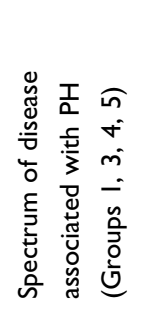 & & $\begin{array}{l}0 \\
0 \\
0 \\
0\end{array}$ & $\begin{array}{l}0 \\
0 \\
0 \\
ن\end{array}$ & $\begin{array}{l}0 \\
\text { ò }\end{array}$ & & \\
\hline 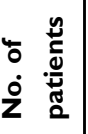 & $\stackrel{\infty}{\sim}$ & 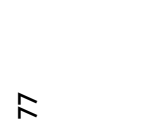 & & $\underline{\underline{o}}$ & $\stackrel{\sim}{\Delta}$ & $\underline{\Xi}$ & & \\
\hline 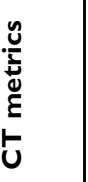 & $\begin{array}{l}\frac{m}{\alpha} \\
+ \\
0 \\
\frac{1}{\Sigma} \\
\Sigma\end{array}$ & $\frac{0}{\frac{1}{\Delta}}$ & & 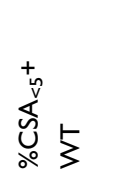 & 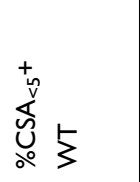 & & 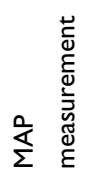 & 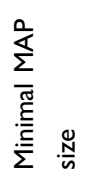 \\
\hline uั & 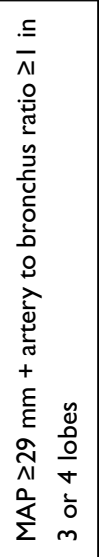 & 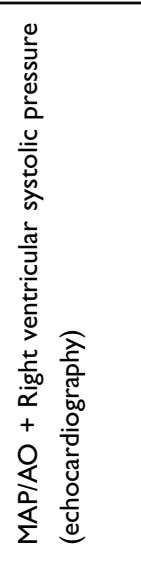 & & 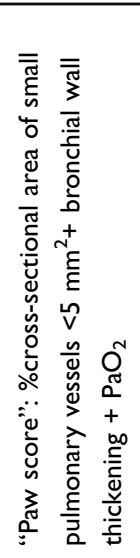 & 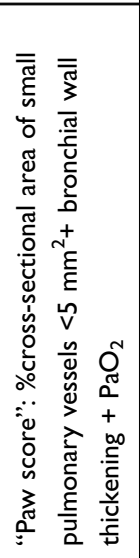 & 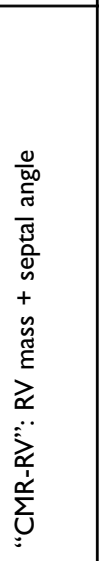 & 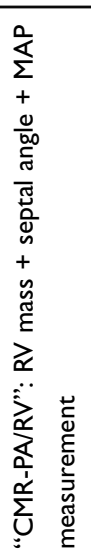 & 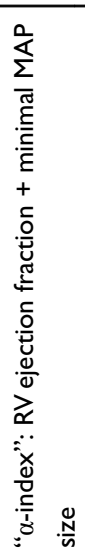 \\
\hline 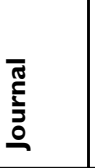 & $\begin{array}{l}\breve{\Delta} \\
\stackrel{\Delta}{U}\end{array}$ & 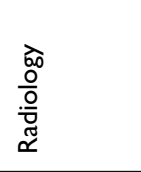 & & $\begin{array}{l}\text { x } \\
\stackrel{x}{0} \\
\stackrel{0}{F}\end{array}$ & 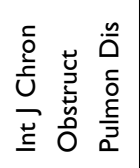 & 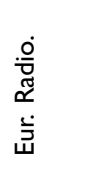 & & \\
\hline 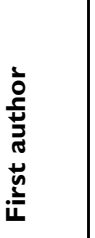 & 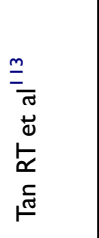 & 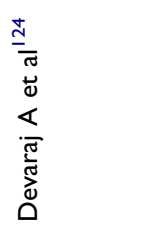 & & 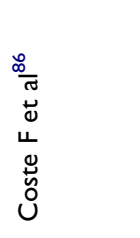 & 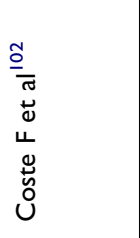 & 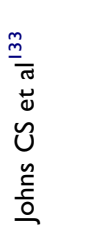 & & \\
\hline 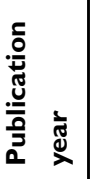 & $\stackrel{\circ}{\sigma}$ & 음 & & $\stackrel{\circ}{\circ}$ & $\frac{\circ}{\bar{N}}$ & $\frac{\infty}{2}$ & & \\
\hline
\end{tabular}


Another index was composed of MAP/AO and right ventricular systolic pressure (RVSP) derived from echocardiography and was correlated with mPAP $\left(R^{2}=0.55\right)^{124}$ for group 1, 3, 4 and 5 of $\mathrm{PH}^{3,4}$

Johns et al mentioned many RV parameters manually measured that are correlated with PH evolution in COPD patients. ${ }^{133}$ They tried to identify the best combination able to predict PH. First combination "cardiac magnetic resonanceRV" ("CMR-RV") included RV mass and septal angle, ${ }^{134}$ second "CMR PA/RV" combined RV mass, septal angle and MAP measurements, and the third " $\alpha$-index" encompass RV ejection fraction (RVEF) and minimal MAP size. ${ }^{135}$ The second model was the best model able to predict mPAP $\geq 25$ $\mathrm{mmHg}$. The same team also confirmed the interest of those results in another recent study using a validation cohort. ${ }^{136}$

We have built a "paw score" in order to predict severe $\mathrm{PH}$ in COPD patients combining CT automated measurements of bronchial wall thickness and pulmonary small vessels areas $\left(\% \mathrm{CSA}_{<5}\right)$ with $\mathrm{PaO}_{2}{ }^{86,102}$

The various scores and their sensitivity are reported in Table 2.

\section{Conclusion}

$\mathrm{PH}$ secondary to COPD is a serious complication that is important to predict with non-invasive tools. Integration of imaging into standard clinical practice is an asset for patient's care. Automated measurements of markers reflecting pulmonary small vessels, bronchial wall and emphysema changes are emerging and might be used routinely in the future for predicting PH or severe PH. All these CT markers could be used in morpho-phenotyping studies. Further studies are required to assess their prognostic impact and follow-up under treatment.

\section{Abbreviations}

AO, aorta; COPD, chronic obstructive pulmonary disease; $\mathrm{CMR}$, cardiac magnetic resonance; $\mathrm{CT}$, computed tomography; $\mathrm{FEV}_{1}$, forced expiratory volume in 1 second; FVC, forced volume capacity; HU, Hounsfield units; LAA\%, lowattenuation area percentage; m, s, dPAP, mean, systolic, diastolic pulmonary arterial pressure; MAP, Main Pulmonary Artery truncus; MRI, magnetic resonance imaging; NA, not attributed; NPV, negative predictive value; PA, pulmonary artery; $\mathrm{PaO}_{2}$, arterial partial pressure of oxygen $(\mathrm{mmHg})$; PFT: pulmonary Function test; PH, pulmonary hypertension; PPV, positive predictive value; RHC, right heart catheterization; RV, right ventricle; WA, bronchial Wall Area (mm); WT, mean bronchial Wall Thickness (mm); 6MWT, 6 mins walk tests; $\% \mathrm{CSA}_{<5}$, percentage of total cross-sectional area of vessels less than $5 \mathrm{~mm}^{2}$ normalized by lung area.

\section{Acknowledgment}

This study has received funding from the Laboratory of Excellence TRAIL, ANR-10-LABX-57.

\section{Author contributions}

All authors contributed to data analysis, drafting or revising the article, gave final approval of the version to be published, and agree to be accountable for all aspects of the work.

\section{Disclosure}

Professor Laurent reports personal fees from BoehringerIngelheim, Roche, and Chiesi, outside the submitted work. Professor Pierre-Olivier Girodet reports personal fees, nonfinancial support from Novartis, personal fees, non-financial support from Chiesi, personal fees, non-financial support from Boehringer-Ingelheim, personal fees, non-financial support from AstraZeneca, personal fees, non-financial support from ALK, outside the submitted work. Professor Patrick Berger reports grants from Novartis, personal fees, non-financial support from AstraZeneca, personal fees, nonfinancial support from Menarini, personal fees, non-financial support from Circassia, personal fees, non-financial support from Sanofi, personal fees from Teva, outside the submitted work; in addition, Prof Berger has a patent Geometric characterization of airways using MRI. 22605-FR pending. The authors report no other conflicts of interest in this work.

\section{References}

1. From the Global Strategy for the Diagnosis, Management and Prevention of COPD, Global Initiative for Chronic Obstructive Lung Disease (GOLD); 2018. Available from: http://www.goldcopd.org/. Accessed July 31, 2009.

2. From the Global Strategy for the Diagnosis, Management and Prevention of COPD, Global Initiative for Chronic Obstructive Lung Disease (GOLD); 2017. Available from: https://goldcopd.org. Accessed July 31, 2009.

3. Galie N, Humbert M, Vachiery JL, et al. 2015 ESC/ERS guidelines for the diagnosis and treatment of pulmonary hypertension. Rev Esp Cardiol. 2016;69(2):177. doi:10.1016/j.recesp.2016.01.002

4. Galie N, Humbert M, Vachiery JL, et al. 2015 ESC/ERS guidelines for the diagnosis and treatment of pulmonary hypertension: the joint task force for the diagnosis and treatment of pulmonary hypertension of the European Society of Cardiology (ESC) and the European Respiratory Society (ERS): endorsed by: association for European Paediatric and Congenital Cardiology (AEPC), International Society for Heart and Lung Transplantation (ISHLT). Eur Heart J. 2016;37(1):67-119. doi:10.1093/eurheartj/ehv317

5. Seeger W, Adir Y, Barbera JA, et al. Pulmonary hypertension in chronic lung diseases. J Am Coll Cardiol. 2013;62(25 Suppl):D109D116. doi:10.1016/j.jacc.2013.10.036

6. Barbera JA, Peinado VI, Santos S. Pulmonary hypertension in chronic obstructive pulmonary disease. Eur Respir J. 2003;21(5):892-905. 
7. Scharf SM, Iqbal M, Keller C, et al. Hemodynamic characterization of patients with severe emphysema. Am J Respir Crit Care Med. 2002;166(3):314-322. doi:10.1164/rccm.2107027

8. Chaouat A, Naeije R, Weitzenblum E. Pulmonary hypertension in COPD. Eur Respir J. 2008;32(5):1371-1385. doi:10.1183/ 09031936.00015608

9. Blanco I, Piccari L, Barbera JA. Pulmonary vasculature in COPD: the silent component. Respirology. 2016;21(6):984-994. doi:10.1111/ resp. 12772

10. Thabut G, Dauriat G, Stern JB, et al. Pulmonary hemodynamics in advanced COPD candidates for lung volume reduction surgery or lung transplantation. Chest. 2005;127(5):1531-1536. doi:10.1378/ chest.127.5.1531

11. Hoeper MM, Humbert M, Souza R, et al. A global view of pulmonary hypertension. Lancet Respir Med. 2016;4(4):306-322. doi:10.1016/S2213-2600(15)00543-3

12. Kessler R, Faller M, Fourgaut G, Mennecier B, Weitzenblum E. Predictive factors of hospitalization for acute exacerbation in a series of 64 patients with chronic obstructive pulmonary disease. Am J Respir Crit Care Med. 1999;159(1):158-164. doi:10.1164/ ajrccm.159.1.9803117

13. Weitzenblum E, Hirth C, Ducolone A, Mirhom R, Rasaholinjanahary J, Ehrhart M. Prognostic value of pulmonary artery pressure in chronic obstructive pulmonary disease. Thorax. 1981;36(10):752-758. doi:10.1136/thx.36.10.752

14. Cooper R, Ghali J, Simmons BE, Castaner A. Elevated pulmonary artery pressure. An independent predictor of mortality. Chest. 1991;99(1):112-120. doi:10.1378/chest.99.1.112

15. Oswald-Mammosser M, Weitzenblum E, Quoix E, et al. Prognostic factors in COPD patients receiving long-term oxygen therapy. Importance of pulmonary artery pressure. Chest. 1995;107 (5):1193-1198. doi:10.1378/chest.107.5.1193

16. Barbera JA, Blanco I. Management of pulmonary hypertension in patients with chronic lung disease. Curr Hypertens Rep. 2015;17 (8):62. doi:10.1007/s11906-015-0574-9

17. Tanabe N, Taniguchi H, Tsujino I, et al. Multi-institutional retrospective cohort study of patients with severe pulmonary hypertension associated with respiratory diseases. Respirology. 2015;20 (5):805-812. doi:10.1111/resp.12530

18. Vitulo P, Stanziola A, Confalonieri M, et al. Sildenafil in severe pulmonary hypertension associated with chronic obstructive pulmonary disease: a randomized controlled multicenter clinical trial. J Heart Lung Transplant. 2017;36(2):166-174. doi:10.1016/j. healun.2016.04.010

19. Andersen KH, Iversen M, Kjaergaard J, et al. Prevalence, predictors, and survival in pulmonary hypertension related to end-stage chronic obstructive pulmonary disease. J Heart Lung Transplant. 2012;31(4):373-380. doi:10.1016/j.healun.2011.11.020

20. Tuder RM, Archer SL, Dorfmuller P, et al. Relevant issues in the pathology and pathobiology of pulmonary hypertension. $\mathrm{J} \mathrm{Am} \mathrm{Coll}$ Cardiol. 2013;62(25 Suppl):D4-D12. doi:10.1016/j.jacc.2013.10.025

21. Chan AL, Juarez MM, Shelton DK, et al. Novel computed tomographic chest metrics to detect pulmonary hypertension. BMC Med Imaging. 2011;11:7. doi:10.1186/1471-2342-11-7

22. Hoeper MM, Lee SH, Voswinckel R, et al. Complications of right heart catheterization procedures in patients with pulmonary hypertension in experienced centers. J Am Coll Cardiol. 2006;48 (12):2546-2552. doi:10.1016/j.jacc.2006.07.061

23. Arcasoy SM, Christie JD, Ferrari VA, et al. Echocardiographic assessment of pulmonary hypertension in patients with advanced lung disease. Am J Respir Crit Care Med. 2003;167(5):735-740. doi:10.1164/rccm.200210-1130OC

24. O'Brien C, Guest PJ, Hill SL, Stockley RA. Physiological and radiological characterisation of patients diagnosed with chronic obstructive pulmonary disease in primary care. Thorax. 2000;55 (8):635-642. doi:10.1136/thorax.55.8.635
25. Fishman A, Martinez F, Naunheim K, et al. A randomized trial comparing lung-volume-reduction surgery with medical therapy for severe emphysema. $N$ Engl J Med. 2003;348(21):2059-2073. doi:10.1056/NEJMoa030287

26. Klooster K, ten Hacken NH, Hartman JE, Kerstjens HA, van Rikxoort EM, Slebos DJ. Endobronchial valves for emphysema without interlobar collateral ventilation. $N$ Engl J Med. 2015;373 (24):2325-2335. doi:10.1056/NEJMoa1507807

27. Reilly J. Using computed tomographic scanning to advance understanding of chronic obstructive pulmonary disease. Proc Am Thorac Soc. 2006;3(5):450-455. doi:10.1513/pats.200604-101AW

28. Leuraud K, Richardson DB, Cardis E, et al. Ionising radiation and risk of death from leukaemia and lymphoma in radiation-monitored workers (INWORKS): an international cohort study. Lancet Haematol. 2015;2(7):e276-e281. doi:10.1016/S2352-3026(15)00094-0

29. Dournes G, Verdier D, Montaudon M, et al. Dual-energy CT perfusion and angiography in chronic thromboembolic pulmonary hypertension: diagnostic accuracy and concordance with radionuclide scintigraphy. Eur Radiol. 2014;24(1):42-51. doi:10.1007/ s00330-013-2975-y

30. Dournes G, Grodzki D, Macey J, et al. Quiet submillimeter MR imaging of the lung is feasible with a PETRA Sequence at $1.5 \mathrm{~T}$. Radiology. 2015;276(1):258-265. doi:10.1148/radiol.15141655

31. Dournes G, Menut F, Macey J, et al. Lung morphology assessment of cystic fibrosis using MRI with ultra-short echo time at submillimeter spatial resolution. Eur Radiol. 2016;26(11):3811-3820. doi:10.1007/s00330-016-4218-5

32. Dournes G, Berger P, Refait J, et al. Allergic bronchopulmonary aspergillosis in cystic fibrosis: MR imaging of airway mucus contrasts as a tool for diagnosis. Radiology. 2017;285(1):261-269. doi:10.1148/radiol.2017162350

33. Dournes G, Yazbek J, Benhassen W, et al. 3D ultrashort echo time MRI of the lung using stack-of-spirals and spherical k-Space coverages: evaluation in healthy volunteers and parenchymal diseases. J Magn Reson Imaging. 2018;48(6):1489-1497. doi:10.1002/jmri.26212

34. Benlala I, Berger P, Girodet PO, Dromer C, Macey J, Laurent F. Automated Volumetric Quantification of Emphysema Severity by Using Ultrashort Echo Time MRI: Validation in Participants with Chronic Obstructive Pulmonary Disease.. Radiology. 2019. Jul;292 (1):216-225. doi:10.1148/radiol.2019190052 (in press).

35. Vonk-Noordegraaf A, Haddad F, Chin KM, et al. Right heart adaptation to pulmonary arterial hypertension: physiology and pathobiology. J Am Coll Cardiol. 2013;62(25 Suppl):D22-D33. doi:10.1016/j.jacc.2013.10.027

36. Reiter U, Reiter G, Fuchsjager M. MR phase-contrast imaging in pulmonary hypertension. Br J Radiol. 2016;89(1063):20150995. doi:10.1259/bjr.20150995

37. Reichelt A, Hoeper MM, Galanski M, Keberle M. Chronic thromboembolic pulmonary hypertension: evaluation with 64-detector row CT versus digital substraction angiography. Eur $J$ Radiol. 2009;71(1):49-54. doi:10.1016/j.ejrad.2008.03.016

38. Tamura M, Yamada Y, Kawakami T, et al. Diagnostic accuracy of lung subtraction iodine mapping $\mathrm{CT}$ for the evaluation of pulmonary perfusion in patients with chronic thromboembolic pulmonary hypertension: correlation with perfusion SPECT/CT. Int J Cardiol. 2017;243:538-543. doi:10.1016/j.ijcard.2017.05.006

39. Resten A, Maitre S, Capron F, Simonneau G, Musset D. [Pulmonary hypertension: CT findings in pulmonary veno-occlusive disease]. J Radiol. 2003;84(11 Pt 1):1739-1745.

40. Mineo G, Attina D, Mughetti M, et al. Pulmonary veno-occlusive disease: the role of CT. Radiol Med. 2014;119(9):667-673. doi:10.1007/s11547-013-0363-y

41. Rajaram S, Swift AJ, Condliffe R, et al. CT features of pulmonary arterial hypertension and its major subtypes: a systematic CT evaluation of 292 patients from the ASPIRE registry. Thorax. 2015;70 (4):382-387. doi:10.1136/thoraxjnl-2014-206088 
42. Hogg JC, Timens W. The pathology of chronic obstructive pulmonary disease. Annu Rev Pathol. 2009;4:435-459. doi:10.1146/ annurev.pathol.4.110807.092145

43. Coxson HO, Dirksen A, Edwards LD, et al. The presence and progression of emphysema in COPD as determined by CT scanning and biomarker expression: a prospective analysis from the ECLIPSE study. Lancet Respir Med. 2013;1(2):129-136. doi:10.1016/S2213-2600(13)70006-7

44. Matsuoka S, Washko GR, Yamashiro T, et al. Pulmonary hypertension and computed tomography measurement of small pulmonary vessels in severe emphysema. Am J Respir Crit Care Med. 2010;181(3):218-225. doi:10.1164/rccm.200908-11890C

45. Dournes G, Laurent F, Coste F, et al. Computed tomographic measurement of airway remodeling and emphysema in advanced chronic obstructive pulmonary disease. Correlation with pulmonary hypertension. Am J Respir Crit Care Med. 2015;191(1):63-70. doi:10.1164/rccm.201408-1423OC

46. Bankier AA, De Maertelaer V, Keyzer C, Gevenois PA. Pulmonary emphysema: subjective visual grading versus objective quantification with macroscopic morphometry and thin-section CT densitometry. Radiology. 1999;211(3):851-858. doi:10.11 48/radiology.211.3.r99jn05851

47. Madani A, Zanen J, de Maertelaer V, Gevenois PA. Pulmonary emphysema: objective quantification at multi-detector row CT-comparison with macroscopic and microscopic morphometry. Radiology. 2006;238(3):1036-1043. doi:10.1148/radiol.2382042196

48. Di Stefano A, Turato G, Maestrelli P, et al. Airflow limitation in chronic bronchitis is associated with T-lymphocyte and macrophage infiltration of the bronchial mucosa. Am J Respir Crit Care Med. 1996;153(2):629-632. doi:10.1164/ajrccm.153.2.8564109

49. O'Shaughnessy TC, Ansari TW, Barnes NC, Jeffery PK. Inflammation in bronchial biopsies of subjects with chronic bronchitis: inverse relationship of CD8+ T lymphocytes with FEV1. Am J Respir Crit Care Med. 1997;155(3):852-857. doi:10.1164/ ajrccm.155.3.9117016

50. Saetta M. Airway inflammation in chronic obstructive pulmonary disease. Am J Respir Crit Care Med. 1999;160(5 Pt 2):S17-S20. doi:10.1164/ajrccm.160.supplement_1.6

51. Burgel PR, Paillasseur JL, Peene B, et al. Two distinct chronic obstructive pulmonary disease (COPD) phenotypes are associated with high risk of mortality. PLoS One. 2012;7(12):e51048. doi:10.1371/journal.pone.0051048

52. Nakano Y, Wong JC, de Jong PA, et al. The prediction of small airway dimensions using computed tomography. Am J Respir Crit Care Med. 2005;171(2):142-146. doi:10.1164/rccm.200407$8740 \mathrm{OC}$

53. Berger P, Perot V, Desbarats P, Tunon-de-Lara JM, Marthan R, Laurent F. Airway wall thickness in cigarette smokers: quantitative thin-section CT assessment. Radiology. 2005;235(3):1055-1064. doi:10.1148/radiol.2353040121

54. Montaudon M, Berger P, de Dietrich G, et al. Assessment of airways with three-dimensional quantitative thin-section CT: in vitro and in vivo validation. Radiology. 2007;242(2):563-572. doi:10.11 48/radiol.2422060029

55. Meng Q, Kitasaka T, Nimura Y, Oda M, Ueno J, Mori K. Automatic segmentation of airway tree based on local intensity filter and machine learning technique in $3 \mathrm{D}$ chest $\mathrm{CT}$ volume. Int J Comput Assist Radiol Surg. 2017;12(2):245-261. doi:10.1007/ s11548-016-1492-2

56. Lo P, van Ginneken B, Reinhardt JM, et al. Extraction of airways from CT (EXACT'09). IEEE Trans Med Imaging. 2012;31 (11):2093-2107. doi:10.1109/TMI.2012.2209674

57. Aykac D, Hoffman EA, McLennan G, Reinhardt JM. Segmentation and analysis of the human airway tree from three-dimensional Xray CT images. IEEE Trans Med Imaging. 2003;22(8):940-950. doi:10.1109/TMI.2003.815905
58. Tschirren J, Hoffman EA, McLennan G, Sonka M. Intrathoracic airway trees: segmentation and airway morphology analysis from low-dose CT scans. IEEE Trans Med Imaging. 2005;24(12):15291539. doi:10.1109/TMI.2005.857654

59. Lo P, Sporring J, Ashraf H, Pedersen JJ, de Bruijne M. Vessel-guided airway tree segmentation: a voxel classification approach. Med Image Anal. 2010;14(4):527-538. doi:10.1016/j.media.2010.03.004

60. Patyk M, Obojski A, Gojny L, Panaszek B, Zaleska-Dorobisz U. Airway evaluation with multidetector computed tomography postprocessing methods in asthmatic patients. Adv Exp Med Biol. 2016;934:41-47. doi:10.1007/5584_2016 23

61. Monzon J, Liu L, Brill H, et al. CDKN2A mutations in multiple primary melanomas. $N$ Engl J Med. 1998;338(13):879-887. doi:10.1056/NEJM199803263381305

62. McDonough JE, Yuan R, Suzuki M, et al. Small-airway obstruction and emphysema in chronic obstructive pulmonary disease. $N$ Engl $J$ Med. 2011;365(17):1567-1575. doi:10.1056/NEJMoa1106955

63. Hogg JC, Macklem PT, Thurlbeck WM. Site and nature of airway obstruction in chronic obstructive lung disease. $N$ Engl $\mathrm{J} \mathrm{Med}$. 1968;278(25):1355-1360. doi:10.1056/NEJM196806202782501

64. Van Brabandt $H$, Cauberghs $M$, Verbeken E, Moerman $P$, Lauweryns JM, Van de Woestijne KP. Partitioning of pulmonary impedance in excised human and canine lungs. J Appl Physiol. 1983;55(6):1733-1742. doi:10.1152/jappl.1983.55.6.1733

65. Yanai M, Sekizawa K, Ohrui T, Sasaki H, Takishima T. Site of airway obstruction in pulmonary disease: direct measurement of intrabronchial pressure. J Appl Physiol. 1992;72(3):1016-1023. doi:10.1152/jappl.1992.72.3.1016

66. Hogg JC, Chu F, Utokaparch S, et al. The nature of small-airway obstruction in chronic obstructive pulmonary disease. $N$ Engl $J$ Med. 2004;350(26):2645-2653. doi:10.1056/NEJMoa032158

67. Berger $\mathrm{P}$, Laurent $\mathrm{F}$, Begueret $\mathrm{H}$, et al. Structure and function of small airways in smokers: relationship between air trapping at CT and airway inflammation. Radiology. 2003;228(1):85-94. doi:10.11 48/radiol.2281020187

68. Matsuoka S, Kurihara Y, Yagihashi K, Hoshino M, Watanabe N, Nakajima Y. Quantitative assessment of air trapping in chronic obstructive pulmonary disease using inspiratory and expiratory volumetric MDCT. AJR Am J Roentgenol. 2008;190(3):762-769. doi:10.2214/AJR.07.2820

69. Gruden JF, Webb WR, Warnock M. Centrilobular opacities in the lung on high-resolution CT: diagnostic considerations and pathologic correlation. AJR Am J Roentgenol. 1994;162(3):569-574. doi:10.2214/ajr.162.3.8109498

70. Xing AP, Hu XY, Shi YW, Du YC. Implication of PDGF signaling in cigarette smoke-induced pulmonary arterial hypertension in rat. Inhal Toxicol. 2012;24(8):468-475. doi:10.3109/08958378.2012.688885

71. Peinado VI, Barbera JA, Ramirez J, et al. Endothelial dysfunction in pulmonary arteries of patients with mild COPD. Am J Physiol. 1998;274(6 Pt 1):L908-L913. doi:10.1152/ajplung.1998.274.6.L908

72. Wrobel JP, McLean CA, Thompson BR, et al. Pulmonary arterial remodeling in chronic obstructive pulmonary disease is lobe dependent. Pulm Circ. 2013;3(3):665-674. doi:10.1086/674339

73. Barbera JA, Peinado VI, Santos S, Ramirez J, Roca J, RodriguezRoisin R. Reduced expression of endothelial nitric oxide synthase in pulmonary arteries of smokers. Am J Respir Crit Care Med. 2001;164(4):709-713. doi:10.1164/ajrccm.164.4.2101023

74. Peinado VI, Barbera JA, Abate P, et al. Inflammatory reaction in pulmonary muscular arteries of patients with mild chronic obstructive pulmonary disease. Am J Respir Crit Care Med. 1999;159(5 Pt 1):1605-1611. doi:10.1164/ajrccm.159.5.9807059

75. Yoshimura K, Suzuki Y, Uto T, Sato J, Imokawa S, Suda T. Morphological changes in small pulmonary vessels are associated with severe acute exacerbation in chronic obstructive pulmonary disease. Int J Chron Obstruct Pulmon Dis. 2016;11:1435-1445. doi:10.2147/COPD.S107424 
76. Matsuoka S, Yamashiro T, Diaz A, et al. The relationship between small pulmonary vascular alteration and aortic atherosclerosis in chronic obstructive pulmonary disease: quantitative CT analysis. Acad Radiol. 2011;18(1):40-46. doi:10.1016/j. acra.2010.08.013

77. Estepar RS, Kinney GL, Black-Shinn JL, et al. Computed tomographic measures of pulmonary vascular morphology in smokers and their clinical implications. Am J Respir Crit Care Med. 2013;188(2):231-239. doi:10.1164/rccm.201301-0162OC

78. Ma J, Yu N, Shen C, Wang Z, He T, Guo YM. A three-dimensional approach for identifying small pulmonary vessels in smokers. J Xray Sci Technol. 2017;25(3):391-402. doi:10.3233/XST-16216

79. Ando K, Kuraishi H, Nagaoka $\mathrm{T}$, et al. Potential role of CT metrics in chronic obstructive pulmonary disease with pulmonary hypertension. Lung. 2015;193(6):911-918. doi:10.1007/s00408015-9813-8

80. Regan EA, Hokanson JE, Murphy JR, et al. Genetic epidemiology of COPD (COPDGene) study design. Copd. 2010;7(1):32-43. doi:10.3109/15412550903499522

81. Mayo JR. CT evaluation of diffuse infiltrative lung disease: dose considerations and optimal technique. J Thorac Imaging. 2009;24 (4):252-259. doi:10.1097/RTI.0b013e3181c227b2

82. Hackx M, Bankier AA, Gevenois PA. Chronic obstructive pulmonary disease: CT quantification of airways disease. Radiology. 2012;265(1):34-48. doi:10.1148/radiol.12111270

83. Madani A, Van Muylem A, Gevenois PA. Pulmonary emphysema: effect of lung volume on objective quantification at thinsection CT. Radiology. 2010;257(1):260-268. doi:10.1148/ radiol.10091446

84. Madani A, De Maertelaer V, Zanen J, Gevenois PA. Pulmonary emphysema: radiation dose and section thickness at multidetector CT quantification-comparison with macroscopic and microscopic morphometry. Radiology. 2007;243(1):250-257. doi:10.1148/ radiol.2431060194

85. Mets OM, Willemink MJ, de Kort FP, et al. The effect of iterative reconstruction on computed tomography assessment of emphysema, air trapping and airway dimensions. Eur Radiol. 2012;22 (10):2103-2109. doi:10.1007/s00330-012-2489-Z

86. Coste F, Dournes G, Dromer C, et al. CT evaluation of small pulmonary vessels area in patients with COPD with severe pulmonary hypertension. Thorax. 2016;71(9):830-837. doi:10.1136/ thoraxjnl-2015-207696

87. Matsuoka S, Yamashiro T, Washko GR, Kurihara Y, Nakajima Y, Hatabu H. Quantitative CT assessment of chronic obstructive pulmonary disease. Radiographics. 2010;30(1):55-66. doi:10.1148/ rg.301095110

88. Gevenois PA, De Vuyst P, de Maertelaer V, et al. Comparison of computed density and microscopic morphometry in pulmonary emphysema. Am J Respir Crit Care Med. 1996;154(1):187-192. doi:10.1164/ajrccm.154.1.8680679

89. Grydeland TB, Dirksen A, Coxson HO, et al. Quantitative computed tomography measures of emphysema and airway wall thickness are related to respiratory symptoms. Am J Respir Crit Care Med. 2010;181(4):353-359. doi:10.1164/rccm.200907-1008OC

90. Biernacki W, Gould GA, Whyte KF, Flenley DC. Pulmonary hemodynamics, gas exchange, and the severity of emphysema as assessed by quantitative CT scan in chronic bronchitis and emphysema. Am Rev Respir Dis. 1989;139(6):1509-1515. doi:10.1164/ ajrccm/139.6.1509

91. Criner GJ, Scharf SM, Falk JA, et al. Effect of lung volume reduction surgery on resting pulmonary hemodynamics in severe emphysema. Am J Respir Crit Care Med. 2007;176(3):253-260. doi:10.1164/rccm.200608-11140C

92. Chaouat A, Savale L, Chouaid C, et al. Role for interleukin-6 in COPD-related pulmonary hypertension. Chest. 2009;136(3):678687. doi:10.1378/chest.08-2420
93. Hurdman J, Condliffe R, Elliot CA, et al. Pulmonary hypertension in COPD: results from the ASPIRE registry. Eur Respir J. 2013;41 (6):1292-1301. doi:10.1183/09031936.00079512

94. Huang YS, Hsu HH, Chen JY, Tai MH, Jaw FS, Chang YC. Quantitative computed tomography of pulmonary emphysema and ventricular function in chronic obstructive pulmonary disease patients with pulmonary hypertension. Korean J Radiol. 2014;15 (6):871-877. doi:10.3348/kjr.2014.15.6.871

95. Madani A, Van Muylem A, de Maertelaer V, Zanen J, Gevenois PA. Pulmonary emphysema: size distribution of emphysematous spaces on multidetector CT images - comparison with macroscopic and microscopic morphometry. Radiology. 2008;248(3):1036-1041. doi:10.1148/ radiol.2483071434

96. Diaz AA, Strand M, Coxson HO, et al. Disease severity dependence of the longitudinal association between CT lung density and lung function in smokers. Chest. 2018;153(3):638-645. doi:10.10 16/j.chest.2017.10.012

97. Johannessen A, Skorge TD, Bottai M, et al. Mortality by level of emphysema and airway wall thickness. Am J Respir Crit Care Med. 2013;187(6):602-608. doi:10.1164/rccm.201209-1722OC

98. Ostridge K, Williams NP, Kim V, et al. Relationship of CTquantified emphysema, small airways disease and bronchial wall dimensions with physiological, inflammatory and infective measures in COPD. Respir Res. 2018;19(1):31. doi:10.1186/ s12931-018-0734-y

99. Grydeland TB, Thorsen E, Dirksen A, et al. Quantitative CT measures of emphysema and airway wall thickness are related to $\mathrm{D}(\mathrm{L}) \mathrm{CO}$. Respir Med. 2011;105(3):343-351. doi:10.1016/j.rmed.2010.10.018

100. Nakano Y, Muro S, Sakai H, et al. Computed tomographic measurements of airway dimensions and emphysema in smokers. Correlation with lung function. Am J Respir Crit Care Med. 2000;162(3 Pt 1):1102-1108. doi:10.1164/ajrccm.162.3.9907120

101. Lee YK, Oh YM, Lee JH, et al. Quantitative assessment of emphysema, air trapping, and airway thickening on computed tomography. Lung. 2008;186(3):157-165. doi:10.1007/s00408-008-9071-0

102. Coste F, Benlala I, Dournes G, et al. Quantitative CT assessment of bronchial and vascular alterations in severe precapillary pulmonary hypertension. Int J Chron Obstruct Pulmon Dis. 2019;14:381-389. doi:10.2147/COPD.S177638

103. Han MK, Kazerooni EA, Lynch DA, et al. Chronic obstructive pulmonary disease exacerbations in the COPDGene study: associated radiologic phenotypes. Radiology. 2011;261(1):274-282. doi:10.1148/radiol.11110173

104. Washko GR, Dransfield MT, Estepar RS, et al. Airway wall attenuation: a biomarker of airway disease in subjects with COPD. J Appl Physiol. 2009;107(1):185-191. doi:10.1152/ japplphysiol.00216.2009

105. Burgel PR, Bourdin A, Chanez P, et al. Update on the roles of distal airways in COPD. Eur Respir Rev. 2011;20(119):7-22. doi:10.1183/ 09059180.10010610

106. Galban CJ, Han MK, Boes JL, et al. Computed tomography-based biomarker provides unique signature for diagnosis of COPD phenotypes and disease progression. Nat Med. 2012;18(11):17111715. doi: $10.1038 / \mathrm{nm} .2971$

107. Iyer AS, Wells JM, Vishin S, Bhatt SP, Wille KM, Dransfield MT. CT scan-measured pulmonary artery to aorta ratio and echocardiography for detecting pulmonary hypertension in severe COPD. Chest. 2014;145(4):824-832. doi:10.1378/chest.13-1422

108. Iliaz S, Tanriverdio E, Chousein EGU, et al. Importance of pulmonary artery to ascending aorta ratio in chronic obstructive pulmonary disease. Clin Respir J. 2018;12(3):961-965. doi:10.1111/ crj. 12612

109. Cuttica MJ, Bhatt SP, Rosenberg SR, et al. Pulmonary artery to aorta ratio is associated with cardiac structure and functional changes in mild-to-moderate COPD. Int $J$ Chron Obstruct Pulmon Dis. 2017;12:1439-1446. doi:10.2147/COPD.S131413 
110. Ortac Ersoy E, Durusu Tanriover M, Ocal S, Gulsun Akpinar M, Topeli A. Measurement of pulmonary artery to aorta ratio in computed tomography is correlated with pulmonary artery pressure in critically ill chronic obstructive pulmonary disease patients. J Crit Care. 2016;33:42-46. doi:10.1016/j.jcrc.2016.01.020

111. Wells JM, Washko GR, Han MK, et al. Pulmonary arterial enlargement and acute exacerbations of COPD. N Engl J Med. 2012;367 (10):913-921. doi:10.1056/NEJMoa1203830

112. Compton GL, Florence J, MacDonald C, Yoo SJ, Humpl T, Manson D. Main pulmonary artery-to-ascending aorta diameter ratio in healthy children on MDCT. AJR Am J Roentgenol. 2015;205 (6):1322-1325. doi:10.2214/AJR.15.14301

113. Tan RT, Kuzo R, Goodman LR, Siegel R, Haasler GB, Presberg KW. Utility of CT scan evaluation for predicting pulmonary hypertension in patients with parenchymal lung disease. Medical college of wisconsin lung transplant group. Chest. 1998;113(5):1250-1256. doi:10.1378/chest.113.5.1250

114. Truong QA, Massaro JM, Rogers IS, et al. Reference values for normal pulmonary artery dimensions by noncontrast cardiac computed tomography: the Framingham Heart Study. Circ Cardiovasc Imaging. 2012;5 (1):147-154. doi:10.1161/CIRCIMAGING.111.968610

115. Shin S, King CS, Brown AW, et al. Pulmonary artery size as a predictor of pulmonary hypertension and outcomes in patients with chronic obstructive pulmonary disease. Respir Med. 2014;108 (11):1626-1632. doi:10.1016/j.rmed.2014.08.009

116. Mohamed Hoesein FA, Besselink T, Pompe E, et al. Accuracy of CT pulmonary artery diameter for pulmonary hypertension in end-stage COPD. Lung. 2016;194(5):813-819. doi:10.1007/s00408-016-9926-8

117. Wells JM, Morrison JB, Bhatt SP, Nath H, Dransfield MT. Pulmonary artery enlargement is associated with cardiac injury during severe exacerbations of COPD. Chest. 2016;149(5):11971204. doi:10.1378/chest.15-1504

118. Wells JM, Iyer AS, Rahaghi FN, et al. Pulmonary artery enlargement is associated with right ventricular dysfunction and loss of blood volume in small pulmonary vessels in chronic obstructive pulmonary disease. Circ Cardiovasc Imaging. 2015;8(4):e002546. doi:10.1161/CIRCIMAGING.114.002546

119. Terzikhan N, Bos D, Lahousse L, et al. Pulmonary artery to aorta ratio and risk of all-cause mortality in the general population: the Rotterdam Study. Eur Respir J. 2017;49(6):1602168. doi:10.1183/ 13993003.02168-2016

120. Revel MP, Faivre JB, Remy-Jardin M, Delannoy-Deken V, Duhamel A, Remy J. Pulmonary hypertension: ECG-gated 64-section CT angiographic evaluation of new functional parameters as diagnostic criteria. Radiology. 2009;250(2):558-566. doi:10.1148/ radiol.2502080315

121. Sanz J, Kariisa M, Dellegrottaglie S, et al. Evaluation of pulmonary artery stiffness in pulmonary hypertension with cardiac magnetic resonance. JACC Cardiovasc Imaging. 2009;2(3):286-295. doi:10.1016/j.jcmg.2008.08.007

122. Ertan C, Tarakci N, Ozeke O, Demir AD. Pulmonary artery distensibility in chronic obstructive pulmonary disease. Echocardiography. 2013;30 (8):940-944. doi:10.1111/echo. 12170
123. Pienn M, Kovacs G, Tscherner M, et al. Non-invasive determination of pulmonary hypertension with dynamic contrast-enhanced computed tomography: a pilot study. Eur Radiol. 2014;24(3):668676. doi:10.1007/s00330-013-3067-8

124. Devaraj A, Wells AU, Meister MG, Corte TJ, Wort SJ, Hansell DM. Detection of pulmonary hypertension with multidetector CT and echocardiography alone and in combination. Radiology. 2010;254(2):609-616. doi:10.1148/radiol.09090548

125. Simonneau G, Gatzoulis MA, Adatia I, et al. Updated clinical classification of pulmonary hypertension. J Am Coll Cardiol. 2013;62(25 Suppl):D34-D41. doi:10.1016/j.jacc.2013.10.029

126. Washko GR, Nardelli P, Ash SY, et al. Arterial vascular pruning, right ventricular size and clinical outcomes in COPD. Am J Respir Crit Care Med. 2019. doi:10.1164/rccm.201811-2063OC

127. Matsuoka S, Washko GR, Dransfield MT, et al. Quantitative CT measurement of cross-sectional area of small pulmonary vessel in COPD: correlations with emphysema and airflow limitation. Acad Radiol. 2010;17(1):93-99. doi:10.1016/j.acra.2009.07.022

128. Uejima I, Matsuoka S, Yamashiro T, Yagihashi K, Kurihara Y, Nakajima Y. Quantitative computed tomographic measurement of a cross-sectional area of a small pulmonary vessel in nonsmokers without airflow limitation. Jpn J Radiol. 2011;29(4):251-255. doi:10.1007/s11604-010-0551-9

129. Park S, Lee SM, Kim N, Seo JB, Shin H. Automatic reconstruction of the arterial and venous trees on volumetric chest CT. Med Phys. 2013;40(7):071906. doi:10.1118/1.4771960

130. Iyer KS, Newell JD Jr, Jin D, et al. Quantitative dual-energy computed tomography supports a vascular etiology of smokinginduced inflammatory lung disease. Am J Respir Crit Care Med. 2016;193(6):652-661. doi:10.1164/rccm.201506-1196OC

131. Payer C, Pienn M, Balint Z, et al. Automated integer programming based separation of arteries and veins from thoracic CT images. Med Image Anal. 2016;34:109-122. doi:10.1016/j.media.2016.05.002

132. Charbonnier JP, Brink M, Ciompi F, Scholten ET, Schaefer-Prokop CM, van Rikxoort EM. Automatic pulmonary artery-vein separation and classification in computed tomography using tree partitioning and peripheral vessel matching. IEEE Trans Med Imaging. 2016;35(3):882-892. doi:10.1109/TMI.2015.2500279

133. Johns CS, Rajaram S, Capener DA, et al. Non-invasive methods for estimating mPAP in COPD using cardiovascular magnetic resonance imaging. Eur Radiol. 2018;28(4):1438-1448. doi:10.1007/ s00330-017-5143-y

134. Swift AJ, Rajaram S, Hurdman J, et al. Noninvasive estimation of PA pressure, flow, and resistance with CMR imaging: derivation and prospective validation study from the ASPIRE registry. JACC Cardiovasc Imaging. 2013;6(10):1036-1047. doi:10.1016/j.jcmg.2013.01.013

135. Moral S, Fernandez-Friera L, Stevens G, et al. New index alpha improves detection of pulmonary hypertension in comparison with other cardiac magnetic resonance indices. Int J Cardiol. 2012;161 (1):25-30. doi:10.1016/j.ijcard.2011.04.024

136. Johns CS, Kiely DG, Rajaram S, et al. Diagnosis of pulmonary hypertension with cardiac MRI: derivation and validation of regression models. Radiology. 2019;290(1):61-68. doi:10.1148/ radiol.2018180603

International Journal of Chronic Obstructive Pulmonary Disease

Dovepress

\section{Publish your work in this journal}

The International Journal of COPD is an international, peer-reviewed journal of therapeutics and pharmacology focusing on concise rapid reporting of clinical studies and reviews in COPD. Special focus is given to the pathophysiological processes underlying the disease, intervention programs, patient focused education, and self management protocols. This journal is indexed on PubMed Central, MedLine and CAS. The manuscript management system is completely online and includes a very quick and fair peer-review system, which is all easy to use. Visit http://www.dovepress.com/testimonials.php to read real quotes from published authors. 